\title{
Implementing Socially Sustainable Practices in Challenging Institutional Contexts: Building Theory from Seven Developing Country Supplier Cases
}

\author{
Fahian Anisul Huq ${ }^{1} \cdot$ Mark Stevenson $^{2}$
}

Received: 6 April 2017 / Accepted: 15 June 2018 / Published online: 23 June 2018

(c) The Author(s) 2018

\begin{abstract}
The implementation of socially sustainable practices in suppliers situated in challenging institutional contexts is examined using institutional theory, both in terms of how institutional pressures affect implementation and what explains the decoupling of practices from the day-to-day reality. A multi-case study approach is employed based on seven apparel industry suppliers in Bangladesh. Cross-case analysis highlights the coercive, mimetic, and normative pressures on suppliers to implement socially sustainable practices. A key pressure identified that has not previously been highlighted in the literature is horizontal collaboration between buyers, which intensifies coercive pressure on suppliers and increases the consequences of non-compliance. The factors that contribute to decoupling are categorized into firm-, supply chain-, and environmentrelated factors. Further, six propositions are developed on how specific forms of institutional pressure can tackle particular decoupling factors to support implementation. The paper responds to recent calls for greater scrutiny of why and how firms decouple ethical practices and supports the development of the literature specifically on social sustainability, which lags behind that on environmental sustainability and has been largely focused on the Western buyer perspective. The findings have implications for the diffusion of ethical practices into supply chains, especially distant suppliers in very different and challenging institutional contexts.
\end{abstract}

Keywords Case study $\cdot$ Decoupling $\cdot$ Institutional theory $\cdot$ Social sustainability $\cdot$ Ethical practices

\section{Introduction}

On the 24th of April 2013, the Rana Plaza, housing five Bangladeshi apparel factories producing garments for Western brands including Primark and Benetton, collapsed killing 1129 people (BBC 2013; Guardian 2013; Huffington Post 2013). This disaster was the deadliest in the apparel industry's history and the deadliest in any industry for over 30 years. Poor working conditions and safety standards are

Fahian Anisul Huq

fahian.huq@manchester.ac.uk

Mark Stevenson

m.stevenson@lancaster.ac.uk

1 Management Sciences and Marketing Division, Alliance Manchester Business School, Manchester University, Manchester M15 6PB, UK

2 Department of Management Science, Lancaster University Management School, Lancaster University, Lancaster LA1 4YX, UK said to have contributed to the large number of fatalities in this disaster (Economist 2013; Time 2013). As a consequence, there has been significant global attention on ethical standards in the Bangladeshi apparel sector and on Western buyers sourcing from these factories. There is an increased expectation that buyers should follow appropriate ethical sourcing practices and ensure that their supply chain partners do the same.

Ethical sourcing refers to the consideration of both green and social issues when making sourcing decisions (Zorzini et al. 2015). We argue that there needs to be more focus on the social aspect of ethical sourcing, especially while sourcing from suppliers in challenging developing country contexts thousands of miles away (Huq et al. 2016; Mani and Gunasekaran 2018). Social issues can directly affect people and their lives, and firms need to implement socially sustainable practices in their supply chains to help "sustain" equity, safety, health, human rights and well-being for employees, local communities, and customers (Klassen and Vereecke 2012; Huq et al. 2014; Zorzini et al. 2015). Thus, socially 
sustainable supply chain management deals with the management of social issues in the supply chain, comprised of human rights, health and safety considerations, and community welfare (Huq et al. 2014).

Supply chain research into socially sustainable practices lags behind the considerable literature on environmentally sustainable practices (Zorzini et al. 2015). Most social studies have focused on the buying firm's perspective of implementing practices and standards, with comparatively few papers considering the supplier's perspective or that of any other stakeholder (Jiang 2009; Ehrgott et al. 2011; Zorzini et al. 2015). Further, the majority of the extant work on socially sustainable practices has been in the context of developed countries (Huq et al. 2014) despite the obvious relevance of this topic to developing countries, i.e., the locations to which many Multi-National Companies (MNCs) have outsourced (Yawar and Seuring 2015). There is a need to extend the existing literature by focusing on the developing country supplier's perspective in order to create a more complete understanding of the phenomenon of implementing socially sustainable practices across the supply chain.

Against this backdrop, we argue that it becomes important to understand the effectiveness of the pressures placed upon suppliers in leading to the genuine implementation of socially sustainable practices. We adopt an institutional theory lens (Meyer and Rowan 1977; Dimaggio and Powell 1983; Zucker 1987; Eisenhardt 1988) to examine case study data collected from Bangladesh, both before and after the Rana Plaza collapse. We explore the pressures exerted on Bangladeshi suppliers by institutional actors, including foreign buyers, workers, trade unions, NGOs, and professional trade bodies; the effectiveness of these pressures on implementation; and how the pressures towards being socially sustainable have evolved over time in response to a critical industry event. Institutional theory posits that there is variation at the beginning of the life cycle of organizational phenomena, but that over time there is structuration and convergence of the field as firms seek to gain legitimacy (DiMaggio and Powell 1983; Eisenhardt 1988). This isomorphism occurs through mainly normative, coercive, and mimetic institutional pressures (DiMaggio and Powell 1983; Grewal and Dharwadkar 2002). But some institutional theorists have also acknowledged that a "decoupling" phenomenon can occur whereby an organizational practice is only adopted symbolically (Meyer and Rowan 1977; Rogers et al. 2007; Boxenbaum and Jonsson 2008). This includes where it is formally adopted by the organization but does not become an established day-to-day routine. This has resonance with the recent disaster in Bangladesh as several factories at Rana Plaza highlighted for their social failings supplied major Western retailers that had strict codes of conduct seemingly in place. Two of the factories had passed the audit of the Business Social Compliance Initiative (BSCI) and were actively supplying BSCI brands at the time of the collapse (IndustriALL 2013).

More in-depth scrutiny into why firms decouple ethical practices and what allows them to do so is required (Greenwood et al. 2011). For example, Kim et al. (2016) highlighted the need to develop an improved understanding of supplier compliance with the ethical sourcing policies of buyers, including whether supplier practices change once they have been caught in unethical situations. Further, Wilhelm et al. (2016) asserted that there should be a special focus on the implementation and decoupling of socially sustainable practices, especially in suppliers based on developing countries and operating in very different institutional contexts. This is because, when compared to environmental sustainability, it is more difficult to determine the impact of social sustainability on performance, detect non-compliance in suppliers, and separate elements of social sustainability from non-economic institutions (Wilhelm et al. 2016). Therefore, in this paper, we ask:

How do institutional pressures affect the implementation of ethical practices in suppliers situated in challenging institutional contexts? More specifically, what explains the decoupling of formal socially sustainable practices from the day-to-day reality?

A multi-case study analysis is presented of seven Bangladeshi suppliers to major European and North American brands. Moreover, data in the form of interviews and published reports were obtained from a broad range of other actors to complement and triangulate the cases, including Western buyers, Non-Government Organizations (NGOs), trade bodies, factory workers, and trade unions. We demonstrate how the suppliers have been influenced by various institutional pressures to implement socially sustainable practices and we identify the firm, supply chain, and broader environmental factors that lead to the decoupling of formal, ethical practices from the day-to-day ground-level realities. We also show how pressure has heightened since the Rana Plaza collapse, particularly in the form of horizontal collaboration between groups of buyers. This has implications for firms looking to diffuse ethical practices into their supply chains, especially into distant suppliers in very different and challenging institutional contexts.

\section{Literature Review}

\section{Social Sustainability: Definition and Relevance}

Sustainability has been defined as a development that meets the needs of the present without compromising the ability of future generations to meet their own needs (Bruntland 1987). But this definition provides only a vague macro perspective 
that does not specify what resources are required by individual organizations to meet those needs (Carter and Rogers 2008). Elkington's (1998) Triple Bottom Line (TBL) perspective on sustainability includes a broader range of issues, including economic, environmental, and social performance. From a global supply chain perspective, organizations operate within a network of inter-dependent relationships and it has been argued that understanding the economic, environmental, and social dimensions of sustainability is crucial (Vachon and Klassen 2008). There have thus been numerous conceptualizations of sustainability specifically in a supply chain context, including those by Carter and Rogers (2008) and Ahi and Searcy (2013). Meanwhile, Seuring and Müller (2008, p. 1700) defined sustainable supply chain management as "the management of material, information and capital flows as well as cooperation among companies along the supply chain while taking goals from all three dimensions of sustainable development, i.e., economic, environmental and social, into account which are derived from customer and stakeholder requirements."

It is important to consider the relationships, synergies, and trade-offs amongst the economic, environmental, and social "pillars" of sustainability (Hutchins and Sutherland 2008; Haffar and Searcy 2017). It is however difficult to implement all three aspects simultaneously in practice and to capture them all in research in order to achieve "true" sustainability (Pagell and Shevchenko 2014). The trend in ethical supply chain management research has therefore been for studies to either focus on environmentally sustainable supply chain management (Ahi and Searcy 2013) or on socially sustainable supply chain management (Huq et al. 2014). It is clear from the numerous recent literature reviews that upstream social issues relating to the human/people-side of sustainability have been under-researched when compared to the environmental agenda (Yawar and Seuring 2015; Zorzini et al. 2015; Kim et al. 2016). Further, Touboulic and Walker (2015) noted that there has been more focus on correlations between environmental and economic performance than between social and economic performance because environmental performance is more quantifiable. Yet social sustainability requires further research in its own right; however, challenging it might be to study the phenomenon.

Social issues are different from environmental issues, and hence, it cannot be assumed that findings on the environmental dimension translate to the social dimension. Social issues are more relevant in certain sectors (e.g., labor intensive industries) and it is harder to measure social performance (Zorzini et al. 2015), mainly because of the dynamic and complex nature of social concerns (Yawar and Seuring 2015). Further, it is generally easier to agree what constitutes best environmental practice (e.g., carbon dioxide reduction) when compared to the social dimension (e.g., practices concerning the use of child labor) due to cultural disparities between countries (Huq et al. 2014; Jia et al. in press) that mean further contextspecific research is required. Moreover, persistent social failures (e.g., the Rana Plaza collapse) affirm that there is insufficient knowledge of what drives organizations to engage in socially sustainable practices and what limits their involvement, especially the challenges of implementing such practices in developing country suppliers (Yawar and Seuring 2015). These suppliers are often situated in very different and challenging institutional contexts compared to their downstream supply chain partners yet, historically, investigation into the institutional environment and its role in implementation has been overlooked (Zhou et al. 2016).

\section{The Developing Country Supplier's Institutional Context}

To understand the motivations and impediments behind the implementation of socially sustainable practices in developing country suppliers, we employ institutional theory as our overarching theoretical anchor. Institutional theory provides a framework that explains how organizations gradually respond to a combination of pressures from actors within their institutional field by converging on a set of homogeneous business practices (DiMaggio and Powell 1983; Grewal and Dharwadkar 2002; Zsidisin et al. 2005), which become the legitimate way to organize (Meyer and Rowan 1977; Zucker 1987). The potential of institutional theory to improve understanding of operations and supply chain phenomena has been identified by a number of authors (Kauppi 2013). It has been used, for example, to unpack the drivers behind the adoption of business continuity planning procedures (Zsidisin et al. 2005), internet-enabled supply chain management systems (Liu et al. 2010), and interorganizational systems across multiple tiers of a healthcare supply chain (Bhakoo and Choi 2013). But its use in the sustainability literature has been mainly limited to the study of environmental practices. To the best of our knowledge, institutional theory has not been used to study the implementation of socially sustainable practices (Touboulic and Walker 2015; Zorzini et al. 2015).

Institutional theory posits that firms adopt organizational practices mainly due to the following three types of pressure (DiMaggio and Powell 1983; Grewal and Dharwadkar 2002):

1. Coercive pressure, mainly exerted by powerful organizations within a network; it can also be cultural or societal.

2. Normative pressure, stemming from professionalization and disseminated via formal education and professional networks. 
3. Mimetic pressure, occurring when an organization, due to uncertainty, copies the actions of successful competitors.

A wide range of institutional actors can exert pressures that influence what becomes legitimate (DiMaggio and Powell 1983; Eisenhardt 1988; Hoffman 2001; Scott 2008). The literature has identified buyer pressure as one of the most important factors behind the implementation of social standards (Maloni and Benton 2000; Luken and Stares 2005; Tencati et al. 2008; Yu 2008). Developing country suppliers face pressure from more powerful buyers who make socially sustainable practices a pre-condition to obtaining orders (Marshall et al. 2016). When an organization is highly dependent on the constituent exerting pressure, as in the case of Bangladeshi apparel suppliers and their Western buyers, it is considered unlikely that the institutional demands and expectations will be resisted (Benton and Maloni 2005; Zhao et al. 2008). Competition amongst suppliers can also be a major factor (Yu 2008; Park-Poaps and Rees 2010). This may help or hinder implementation, depending on whether social improvements are viewed as a cost or potential source of competitive advantage.

Internal actors, including owners/managers (Baden et al. 2009) and senior management (Walker and Jones 2012), are also influential while governments can impact social conduct through regulation and laws (Lim and Phillips 2008; Yu 2008; Lee and Kim 2009). It has also been suggested that NGOs (Mamic 2005; Tsoi 2010; Ehrgott et al. 2011) and trade unions (Lipschutz 2004) play a positive role in pressurizing firms into being socially sustainable. Finally, professional networks, including trade bodies, can have an effect, including by providing education on social sustainability issues (Hoffman 2001; Campbell 2007).

\section{Implementation of Socially Sustainable Practices in Developing Country Suppliers}

There are various tools for implementing socially sustainable practices in supply chains, ranging from a buyer's own code of conduct to third-party standards and supplier development programmes. There remains however a lack of knowledge in the literature on how MNCs can implement socially sustainable practices across their supply chains to enhance social performance (Klassen and Vereecke 2012; Zorzini et al. 2015). Based on a thorough review of the supply chain ethics and sustainability literature, we identify six main composite practices. These six dimensions in particular were considered to be key to facilitating and encouraging social sustainability in developing country suppliers. Below we present a discussion on why these factors are important for our research context (see also Table 1, which includes a list of key references).
It is known that the general attitude of suppliers towards compliance is an important factor (Marshall et al. 2015), which can be reflected in the scope of the practices adopted. This scope can vary from compliance with local laws only to complete compliance (or beyond) with buyers' own codes of conduct (Gugler and Shi 2009) or with third-party certifications (Ciliberti et al. 2009). Like the scope, the depth of the compliance behavior can also differ, with instances of suppliers carrying out 'mock compliance' being reported (Huq et al. 2014) and buyers subsequently displacing their responsibility (Eriksson and Svensson 2016). Infrastructure within supplier firms to support the implementation of socially sustainable practices also varies. It has been found that having dedicated staff or departments dealing with the implementation of socially sustainable practices leads to better implementation when compared with suppliers having no specialized staff, where a broad human resource department is left to oversee implementation (Gattiker and Carter 2010; Huq et al. 2016). The role of education and awareness in implementing socially sustainable practices across the firm has also been highlighted as a reason for better implementation (Mamic 2005; Awaysheh and Klassen 2010).

Meanwhile, an inter-organizational collaborative approach can help to develop social sustainability implementation capabilities (Klassen and Vereecke 2012; Eriksson and Svensson 2016). Firms can gain legitimacy by making stakeholders inclusive to the implementation process (Mueller et al. 2009) and the resources and capabilities that develop from such collaborations can lead to sustained competitive advantage, especially since these are difficult to imitate as they are the result of long-term, complex relationships (Gold et al. 2010).

Finally, recent research has shown that social sustainability leadership in terms of being proactive and striving for the continuous development of innovative implementation tools and procedures leads to better implementation (Huq et al. 2016). There is however limited knowledge on what drives implementation efforts in suppliers, especially in developing country suppliers (Ehrgott et al. 2011; Gimenez and Tachizawa 2012; Zhou et al. 2014).

\section{Institutional Decoupling of Socially Sustainable Practices}

The pressures exerted by institutional actors do not always lead to implementation. Instead, heterogeneous responses may occur, including compromise, avoidance, defiance, and manipulation (Oliver 1991). Meyer and Rowan (1977) suggested that an organization may respond to institutional pressures through superficial conformity. This "decoupling" of pressure from expected response arises when adaptations to institutional pressures have uncertain efficiency consequences (Meyer and Rowan 1977; Rogers et al. 2007; 


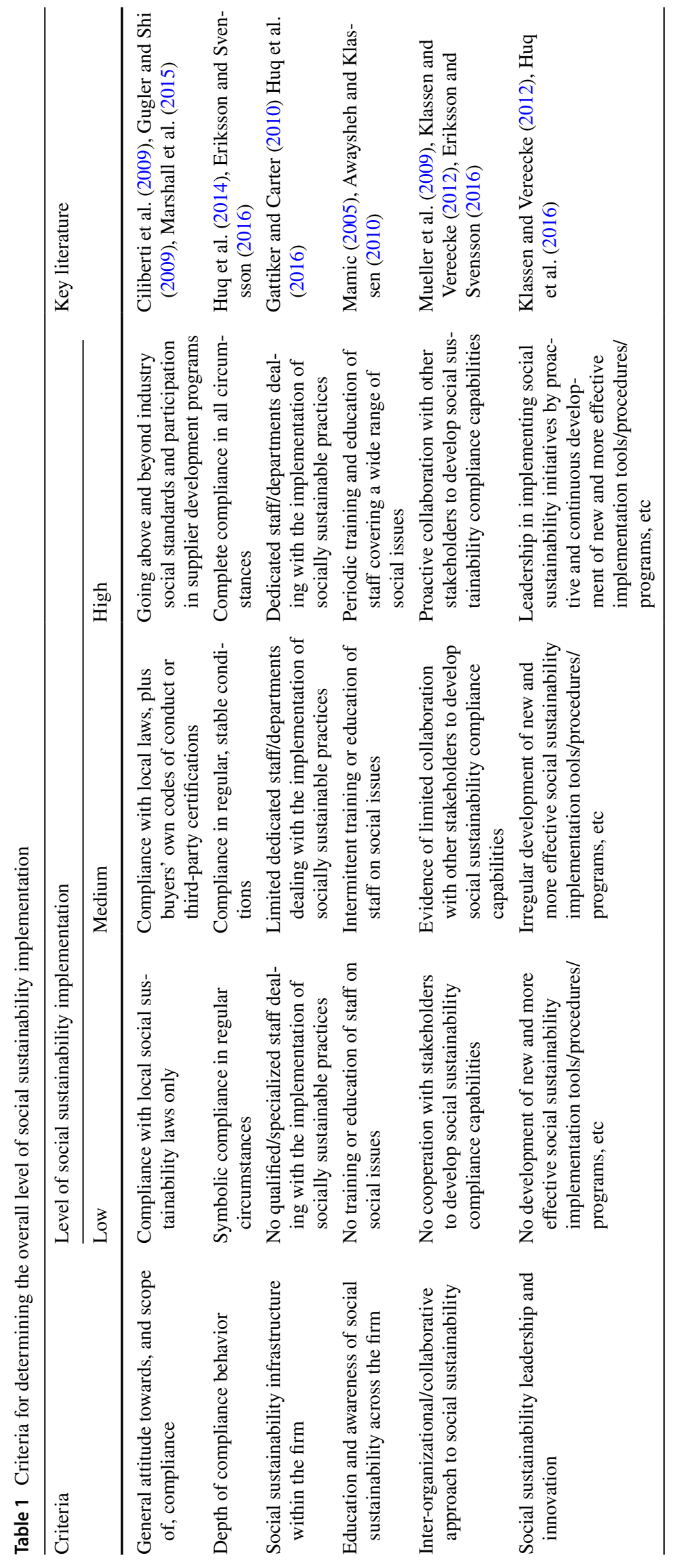


Boxenbaum and Jonsson 2008), if they contradict internal efficiency needs, i.e., create potential trade-offs in priorities (Meyer and Rowan 1977), when practices do not reflect local circumstances or realities (Scott 2008), or when there is information asymmetry between firms and their stakeholders (Crilly et al. 2012). A case in point is the apparel supply chain, which included a number of incidents of social failure indicating a decoupling between the socially sustainable policies adopted by buyers and the actual implementation of socially sustainable practices in suppliers. For example, several factory fires led up to the collapse of the Rana Plaza in Bangladesh in 2013, including a fire in a factory supplying apparel to major branded clothing companies such as WalMart and SEARS in November 2012 (Tazreen), resulting in the loss of 117 lives (Bloomberg 2012). It was claimed that the Tazreen factory had been assessed by third-party auditors (New York Times 2012) yet post-fire investigations revealed the factory had no emergency exits and that the gates were locked from the outside (BBC 2014). It was also claimed workers were poorly trained on how to extinguish fires and on evacuation procedures. It seemed that, in many cases, the focal actors were complying superficially because being compliant legitimized their business. Suppliers were clearly decoupling formal compliance from ground-level organizational practices. Implementation may be viewed by suppliers as an extra cost, especially during constrained economic times (Barnett et al. 2015). Thus, if the economic benefit of implementation is not apparent then suppliers can act opportunistically (Huq et al. 2014) and any action taken may be only a symbolic response to external legitimacy pressures.

Institutional fields typically face multiple institutional logics-a set of material practices and symbolic constructions that constitute an institutional order's organizing principles (Friedland and Alford 1991). These institutional logics may complement each other when synergies exist (Montabon et al. 2016), but they can also compete or conflict (Friedland and Alford 1991; Thornton et al. 2012). For example, in the supply network of a sustainability-oriented agricultural cooperative, there can be market-oriented and community-oriented logics, which can co-exist but promote different behaviors (Wu and Pullman 2015). The literature on institutional logics suggests that institutional pressures may lead to heterogeneous rather than homogeneous responses if contending logics co-exist (Thornton and Ocasio 1999). Hence, the presence of conflicting logics has been suggested as one explanation for decoupling (Meyer and Rowan 1977). Yet further examination of how and under what circumstances such trade-offs can become complementary has been called for by Haffar and Searcy (2017).

Decoupling is a well-recognized organization-level response (Boxenbaum and Jonsson 2008). For example, opportunism has been identified as one of the reasons for ill-intentioned non-compliant purchasing behavior (Karjalainen et al. 2008). It can also be due to different development patterns in emerging markets, including a lack of infrastructure and resources, also referred to as 'institutional voids' (Khanna et al. 2005). However, more in-depth scrutiny is required into why firms decouple and what allows them to do so (Greenwood et al. 2011). Further, Rogers et al. (2007) highlighted the need to develop an improved understanding of how to cope with decoupling phenomena. More recently, Wilhelm et al. (2016) asserted that there should be a special focus on the implementation and decoupling of socially sustainable practices in suppliers located in developing countries that have a different institutional context. They argued that, because of the inherent nature of social sustainability, it is difficult to separate out the institutional context while studying the implementation of social sustainability.

It has also been suggested that critical events may shift or de-legitimize pre-existing institutional structures (Thornton et al. 2005), creating opportunities to re-evaluate the costs, trade-offs, and benefits of such organizational practices (Sine and David 2003). Institutional logics are important in understanding how attitudes towards the implementation of socially sustainable practices are evolving over time in response to critical industry events. In the context of social sustainability, the two relevant logics are argued to be the economic and social logics. Institutional logics have been studied at the societal, field, and industry level, but very little systematic attention has been paid to how individual organizations react to the multiplicity and incompatibility of logics (Greenwood et al. 2011). Meanwhile, the studies by Rogers et al. (2007) and Wu and Pagell (2011) on competing logics/priorities used static or cross-sectional data. They did not explore how logics/priorities evolve over time. It is argued here to be important to investigate how logics interplay and evolve in developing country supplier firms as events take place to influence the implementation of socially sustainable practices.

Thus, more empirical research into the determinants and deterrents behind implementing ethical practices in developing country suppliers, particularly socially sustainable practices, is necessary (Blome and Paulraj 2013). These major themes from institutional theory lay the foundations for us to explore our research questions concerning how institutional pressures affect the implementation of socially sustainable practices in suppliers situated in challenging institutional contexts; and what explains the decoupling of such formal organizational practices from the day-to-day reality. We contend that this is the logical first step as these antecedents may become contingency factors in future social sustainability-performance relationship studies. 


\section{Methodology}

The nascent state of the literature on socially sustainable practices, especially in a developing country supplier context, called for an exploratory study (Saunders et al. 2009). The case study method is therefore suitable as it allows for the thorough examination of this complex, real-life issue on which little prior empirical evidence is available, leading to new, in-depth insights (Eisenhardt 1989; Edmondson and McManus 2007; Yin 2009). Further, it supports our extraction of rich data through a range of techniques (e.g., interviews, observations, and document analysis) and facilitates cross-validation (Seuring 2008; Yin 2009). A multiple case study approach is adopted here, which can aid external validity, guard against observer bias (Voss et al. 2002; Barratt et al. 2011), aid triangulation, and create more testable and robust theory (Eisenhardt 1989; Yin 2009).

\section{Research Context and Case Selection}

Bangladesh is a major international player in the laborintensive apparel sector and has been the subject of much public scrutiny. This developing country exported apparel worth $\$ 28$ billion in 2015/2016, second only to China (McKinsey 2011; BGMEA 2016). However, since 2005, nearly 2000 apparel workers have reportedly died in industrial accidents in Bangladesh (CNN 2013). For example, the Spectrum factory collapse killed 64 people in 2005, the Hameem Group factory fire killed 29 people in 2010, and the Rana Plaza collapse killed 1129 people in 2013. These tragic events have been linked to social failings yet the factories in question had successfully passed various audit checks suggesting a disconnection between the formal adoption of socially sustainable practices and the ground-level reality. Thus, the apparel sector in Bangladesh is suitable for studying the phenomenon of the adoption of ethical practices in a developing country, in particular the adoption (and decoupling) of socially sustainable practices.

We focused on the developing country supplier's perspective as it was evident from the literature that this required more scrutiny (Zorzini et al. 2015). In particular, we sought to understand how adoption in developing country suppliers is influenced by institutional pressures and why, where relevant, the ground realities have been decoupled from formal, audited practices. Thus, the unit of analysis was the supplier firm interpreted in the institutional context of a developing nation.

Consistent with theoretical sampling, cases were selected opportunistically, i.e., according to their ability to generate new insights that would help in the development of theory (Eisenhardt 1989). Firms were selected from the Bangladeshi apparel industry that were known to supply international customers, i.e., MNCs sourcing from Bangladesh with a minimum revenue of $\$ 3$ billion. Fourteen supplier firms were approached but were only included if multiple interviewees were available and on-site access was provided. This facilitated triangulation and allowed for observations to inform data collection and interpretation. Further, the set of cases was limited to supplier firms where interviews could also take place in at least one of its international buyers to provide further triangulation. In total, seven suppliers were studied that met the criteria. These seven cases were enough to reach a satisfactory level of theoretical saturation. For example, as data collection approached the end, evidence to support the introduction of new categories of decoupling could not be found. Rather, new evidence only confirmed previously identified categories. Data collection therefore stopped as additional data would not have increased our understanding of the research question (Pagell and Wu 2009).

\section{Data Collection}

Data collection took place between December 2011 and May 2015. We followed Yin's (2009) call for multiple sources of evidence. The primary sources were 19 semi-structured interviews conducted before the Rana Plaza collapse in 2013 with managers from the seven supplier firms (see Table 2). These interviews focused on current social sustainability attitudes and related pressures. For instance, on the issue of institutional pressures faced by supplier firms, we asked what the interviewees thought were the roles of the different institutional actors in exerting pressure and how they would describe this type of pressure. On the decoupling dimension, for example, we tried to determine what kinds of challenges the interviewees were facing in adopting buyers' social standards and asked them to describe the implementation process. We also probed their motivations and efforts to make their business more socially sustainable. The interviews were supplemented by supplier factory tours and secondary data, e.g., audit reports and news articles. These additional sources were used to inform our understanding of the institutional context and helped us to validate the insights that we received from our primary interviewees.

A further 23 semi-structured interviews were conducted with other relevant institutional actors (see also Table 2). The core set of seven supplier cases was supplemented by evidence from six different buyers from North America and Europe, with apparel sales ranging from \$3bn to over \$20bn. Evidence was also collected from one local and one international Chamber of Commerce, an apparel trade body, two trade unions, and two NGOs. In addition, two Focus Group 
Table 2 Profiles of companies and interviewees

\begin{tabular}{|c|c|c|c|c|c|c|}
\hline \multirow[t]{2}{*}{ Company } & \multirow[t]{2}{*}{ Size } & \multirow{2}{*}{$\begin{array}{l}\text { Key buyers/suppliers } \\
\text { also interviewed }\end{array}$} & \multirow[t]{2}{*}{ Interviewee(s) } & \multicolumn{3}{|c|}{ No. of Interviews/FGDs } \\
\hline & & & & $\begin{array}{l}\text { Before } \\
\text { Rana col- } \\
\text { lapse }\end{array}$ & $\begin{array}{l}\text { After } \\
\text { Rana col- } \\
\text { lapse }\end{array}$ & $\overline{\text { Total }}$ \\
\hline \multicolumn{7}{|l|}{ Core set of cases } \\
\hline Supplier 1 & 700 workers & Buyer 6 & $\begin{array}{l}\text { Managing Director (MD); } \\
\text { Executive Director; Direc- } \\
\text { tor; HR and Compliance } \\
\text { Manager }\end{array}$ & 3 & 3 & 6 \\
\hline Supplier 2 & 2400 workers & Buyer 2 and 6 & $\begin{array}{l}\text { HR Manager; Compliance } \\
\text { Manager }\end{array}$ & 2 & 0 & 2 \\
\hline Supplier 3 & 1500 workers & Buyers 4 and 6 & $\begin{array}{l}\text { MD; Deputy MD (DMD); } \\
\text { HR Manager }\end{array}$ & 3 & 2 & 5 \\
\hline Supplier 4 & 7000 workers & Buyer 1,2 and 6 & $\begin{array}{l}\text { MD; COO; Compliance } \\
\text { Manager }\end{array}$ & 3 & 0 & 3 \\
\hline Supplier 5 & 1400 workers & Buyer 1, 2, 3, 4 and 6 & $\begin{array}{l}\text { Chairman; CEO; HR and } \\
\text { Compliance Manager }\end{array}$ & 3 & 0 & 3 \\
\hline Supplier 6 & 3000 workers & Buyer 5 & $\begin{array}{l}\text { Chairman; Director; HR } \\
\text { Manager }\end{array}$ & 3 & 1 & 4 \\
\hline Supplier 7 & 17,000 workers & Buyer 1 & $\begin{array}{l}\text { Head of Sustainability; Dis- } \\
\text { tribution Executive }\end{array}$ & 2 & 2 & 4 \\
\hline \multicolumn{7}{|c|}{ Supplementary/supporting evidence } \\
\hline Buyer 1 (European) & $>\$ 10$ billion & Suppliers 4, 5 and 10 & $\begin{array}{l}\text { Country Manager; Supply } \\
\text { Chain Manager; Compli- } \\
\text { ance Executive }\end{array}$ & 3 & 0 & 3 \\
\hline Buyer 2 (European) & $\$ 5-10$ billion & Suppliers 3,4 and 5 & Head of Compliance & 1 & 1 & 2 \\
\hline Buyer 3 (North American) & $\$ 3-5$ billion & Supplier 5 & Country Manager & 1 & 1 & 2 \\
\hline Buyer 4 (European) & $>\$ 20$ billion & Suppliers $2,6,5$ & $\begin{array}{l}\text { Logistics Manager; Sustain- } \\
\text { ability Manager }\end{array}$ & 2 & 0 & 2 \\
\hline Buyer 5 (European) & $>\$ 20$ billion & Supplier 7 & CSR Manager & 1 & 0 & 1 \\
\hline Buyer 6 (North American) & $>\$ 20$ billion & Suppliers 1, 2, 3, 4 and 5 & Sourcing Manager & 1 & 1 & 2 \\
\hline $\begin{array}{l}\text { International Chamber of } \\
\text { Commerce }\end{array}$ & Unknown & N/A & President & 1 & 0 & 1 \\
\hline $\begin{array}{l}\text { Local Chamber of Com- } \\
\text { merce }\end{array}$ & 426 member bodies & N/A & Director & 1 & 0 & 1 \\
\hline Apparel Trade Body & 5150 member factories & N/A & $\begin{array}{l}\text { Vice President; Deputy } \\
\text { Secretary }\end{array}$ & 2 & 2 & 4 \\
\hline Trade Union 1 & 80,000 members & N/A & President; General Secretary & 2 & 2 & 4 \\
\hline Trade Union 2 & 11,000 members & N/A & $\begin{array}{l}\text { President; General Secretary; } \\
\text { Organisational Secretary }\end{array}$ & 3 & 0 & 3 \\
\hline $\begin{array}{l}\text { Local Non-Government } \\
\text { Organisation (NGO1) }\end{array}$ & N/A & N/A & $\begin{array}{l}\text { Chairwoman; General Secre- } \\
\text { tary; Operations Director }\end{array}$ & 3 & 2 & 5 \\
\hline $\begin{array}{l}\text { International Non-Gov- } \\
\text { ernment Organisation } \\
(\mathrm{NGO} 2)\end{array}$ & N/A & N/A & Manager & 0 & 1 & 1 \\
\hline $\begin{array}{l}\text { Worker Focus Group Dis- } \\
\text { cussion } 1 \text { (FGD1) }\end{array}$ & N/A & N/A & 12 workers & 1 & 0 & 1 \\
\hline $\begin{array}{l}\text { Worker Focus Group Dis- } \\
\text { cussion } 2 \text { (FGD2) }\end{array}$ & N/A & N/A & 9 workers & 1 & 0 & 1 \\
\hline
\end{tabular}

Discussions (FGDs: FGD1 and FGD2) were conducted with apparel industry workers with industry experience ranging from 1 to 16 years. FGD1 consisted of 12 workers from 10 different suppliers and FGD2 consisted of 9 workers from 9 different suppliers. These FGDs were conducted in two separate locations, where there was a concentration of apparel suppliers, and they did not include any employees from the seven case firms. These additional sources of data 
represented many of the institutional actors exerting pressure on implementation. The supplementary interviews provided context and helped obtain both a balanced view and a comprehensive picture of the institutional environment. They also helped us stay objective and triangulate collected information from supplier interviewees with opposing or confirmatory arguments. For example, Table 6 later provides a description of the decoupling coding categories (first column) and the third and fourth columns illustrate how we used the data from these supplementary interviews (buyers and other institutional actors) to triangulate each decoupling factor with the suppliers (second column).

On average, each interview lasted $45 \mathrm{~min}$ and most were audio-recorded or accompanied by comprehensive notetaking. Most interviews were conducted in English (except those with the workers and lower management) as English is widely used in business conversations and communication in Bangladesh (Mundi 2011; Uk Trade \& Investment 2015). However, during the interviews there would be interjections or further explanations in the Bengali language to add a more informal and conversational style. Where necessary, these were then translated into English by the first author who is fluent in both Bangla and English and thus there were no problems with comprehension. Unclear issues were clarified through follow-up e-mails or telephone calls. Initial interviewees were identified through personal contacts and referrals from a previous interviewee, ensuring participants were both accessible and cooperative (Bryman and Bell 2007). Time was spent building trust with the interviewees to enable 'frank and open' discussions, which would otherwise have been difficult given the sensitive nature of the research. This was also aided by the first author and interviewer being a Bangladeshi native.

During the data collection period, the industry suffered a major disaster - the collapse of the Rana Plaza building. This was the world's deadliest industrial incident since the 1984 Bhopal disaster in India, as well as being the deadliest structural failure in modern human history, killing almost 1200 people. Even though other failures had occurred in the industry, they were nowhere near on this magnitude. Such critical events can trigger institutional change and industry evolution (Thornton et al. 2005) thereby creating prospects for institutional actors to re-evaluate the costs and benefits of existing practices (Sine and David 2003). This offered a unique opportunity to study first-hand the evolution of industry pressures and their effect on the implementation of socially sustainable practices, which would not be possible in environments of stasis. Further, this enabled us to conduct a before-and-after analysis of the change in pressures and the subsequent effect on decoupling. These kinds of opportunities are very rare, especially in qualitative studies.

According to Eisenhardt (1989), if an opportunity presents itself to take advantage of the uniqueness of a specific case and provide new theoretical insights, then researchers can make alterations during the data collection process through "controlled opportunism" (Eisenhardt 1989, p. 539). This is essentially what we did when the Rana Plaza disaster occurred; but it was understandably not possible to obtain perfect symmetry between the before and after data (Huq et al. 2016). New (2015) acknowledged that, in researching unsustainable social practices, researchers might find the data harder to collect and it could be necessary to adopt certain 'investigative journalist' approaches. As expected, given the sensitivity of the issues covered, access became more difficult and respondents were more reluctant to share information, and thus, it was not possible to conduct further interviews in all seven suppliers. Through our interactions during the first round of data collection before the Rana Plaza collapse, we were able to gain trust and build comparatively stronger relationships with four of the seven suppliers allowing us to conduct an additional eight post-disaster interviews in these firms. These suppliers were more willing to be involved with the study and, after the Rana Plaza disaster, the relevance of the topic became more evident to them.

This sub-set sample of four cases was however balanced as it covered suppliers showing a low, moderate, and high level of social sustainability performance, as explained fully in Sect. 3.3. It included the best and worst performing suppliers in terms of their level of social sustainability and two moderates (see Table 3). The two polar cases (high vs. low) facilitated building theory on success and failure in implementing socially sustainable practices in challenging institutional contexts (Eisenhardt 1989) while the two moderates helped us cover the entire spectrum and address issues of confirmability and credibility by increasing variance in the data (Wu et al. 2010).

To conduct more substantive and critical work while investigating controversial social failures, it has been suggested that researchers should try to incorporate a wider view, i.e., to include more sources of information than the firms themselves and to try to understand the broader institutional context of the phenomena under exploration (New 2015). Therefore, similar to data collection before the Rana Plaza disaster, the post-Rana supplier interviews were also augmented by ten further interviews in four of the buyers, two NGOs, one labor union, and the Apparel Trade Body (see Table 2). However, we were unable to re-instate the FGDs in this phase and, besides, it would not have been possible to gain collective access to the same group of workers as many were migrant workers from remote regions and the rate of labor turnover is quite high (McKinsey 2011).

Since some of the interviews took place shortly after this critical industry event, there is a chance that interviewees gave 'knee-jerk' reactions, leading to biased data through retrospective sense-making by image-conscious informants. However, it is argued that the risk of this is minimized as 
Table 3 Type and frequency of institutional pressure on suppliers

\begin{tabular}{|c|c|c|c|c|c|c|c|c|c|}
\hline \multirow{3}{*}{$\begin{array}{l}\text { Core category of } \\
\text { institutional pressure }\end{array}$} & \multirow{3}{*}{$\begin{array}{l}\text { Sub-category of insti- } \\
\text { tutional pressure }\end{array}$} & \multicolumn{7}{|c|}{ Level of social sustainability implementation } & \multirow[t]{3}{*}{ Frequency } \\
\hline & & \multicolumn{2}{|l|}{ Low } & \multicolumn{4}{|l|}{ Moderate } & \multirow{2}{*}{$\begin{array}{l}\text { High } \\
\text { Supplier } 7\end{array}$} & \\
\hline & & Supplier 1 & Supplier 2 & Supplier 3 & Supplier 4 & Supplier 5 & Supplier 6 & & \\
\hline \multirow[t]{5}{*}{ Coercive } & Buyers & $\mathrm{Y}$ & $\mathrm{Y}$ & $\mathrm{Y}$ & $\mathrm{Y}$ & $\mathrm{Y}$ & $\mathrm{Y}$ & $\mathrm{Y}$ & 7 \\
\hline & $\begin{array}{l}\text { Professional trade } \\
\text { bodies/associations }\end{array}$ & $\mathrm{Y}$ & $\mathrm{Y}$ & $\mathrm{Y}$ & $\mathrm{N}$ & $\mathrm{N}$ & $\mathrm{Y}$ & $\mathrm{N}$ & 4 \\
\hline & Government & $\mathrm{Y}$ & $\mathrm{N}$ & $\mathrm{N}$ & $\mathrm{N}$ & $\mathrm{N}$ & $\mathrm{Y}$ & $\mathrm{N}$ & 2 \\
\hline & Trade unions/workers & $\mathrm{N}$ & $\mathrm{N}$ & $\mathrm{N}$ & $\mathrm{N}$ & $\mathrm{N}$ & $\mathrm{N}$ & $\mathrm{N}$ & 0 \\
\hline & NGOs/rights groups & $\mathrm{N}$ & $\mathrm{N}$ & $\mathrm{N}$ & $\mathrm{N}$ & $\mathrm{N}$ & $\mathrm{N}$ & $\mathrm{N}$ & 0 \\
\hline \multirow[t]{2}{*}{ Mimetic } & $\begin{array}{l}\text { Competitors (and } \\
\text { competition for } \\
\text { orders) }\end{array}$ & $\mathrm{Y}$ & $\mathrm{Y}$ & $\mathrm{Y}$ & $\mathrm{Y}$ & $\mathrm{Y}$ & $\mathrm{Y}$ & $\mathrm{N}$ & 6 \\
\hline & $\begin{array}{l}\text { Workers (and compe- } \\
\text { tition for workers) }\end{array}$ & $\mathrm{Y}$ & $\mathrm{N}$ & $\mathrm{Y}$ & $\mathrm{N}$ & $\mathrm{Y}$ & $\mathrm{Y}$ & $\mathrm{N}$ & 4 \\
\hline \multirow{3}{*}{$\begin{array}{l}\text { Normative (educa- } \\
\text { tion, training and } \\
\text { awareness building } \\
\text { of/by) }\end{array}$} & $\begin{array}{l}\text { Owners/mid-manage- } \\
\text { ment }\end{array}$ & $\mathrm{N}$ & $\mathrm{N}$ & $\mathrm{Y}$ & $\mathrm{Y}$ & $\mathrm{Y}$ & $\mathrm{Y}$ & $\mathrm{Y}$ & 5 \\
\hline & Workers & $\mathrm{N}$ & $\mathrm{N}$ & $\mathrm{N}$ & $\mathrm{N}$ & $\mathrm{N}$ & $\mathrm{N}$ & $\mathrm{Y}$ & 1 \\
\hline & $\begin{array}{l}\text { Professional trade } \\
\text { bodies }\end{array}$ & $\mathrm{Y}$ & $\mathrm{Y}$ & $\mathrm{Y}$ & $\mathrm{Y}$ & $\mathrm{Y}$ & $\mathrm{Y}$ & $\mathrm{Y}$ & 7 \\
\hline
\end{tabular}

our data came from a range of highly knowledgeable institutional actors that viewed the focal phenomena from different perspectives (Eisenhardt and Graebner 2007).

\section{Data Analysis}

Data analysis followed procedures recommended by Eisenhardt (1989) and Miles et al. (2014). Specific techniques were followed to establish rigor through confirmability, dependability, credibility, and transferability. Based on the transcripts, interviewer notes, and secondary data, we first compiled individual case studies for supplier firms, including their level of social compliance and the types of institutional pressure they were facing. As there were no established criteria for measuring the level of social sustainability implementation, we used six proxies identified from the literature (see Sect. 2.2) to gauge the level of social sustainability of supplier firms, including their general attitude towards compliance (e.g., with local laws and buyer/ third-party codes of conduct), the depth of their compliance, the social sustainability infrastructure within the firm, and inter-organizational/collaborative approaches to social sustainability (see Table 1). The laggards-Supplier 1 and 2were rated low on all six criteria, while the leader-Supplier 7 - scored high on all six criteria. Those suppliers having a moderate level of implementation-Suppliers 3-6-were rated medium on the majority of criteria (i.e., no more than two criteria rated either high or low). We then expanded the individual case descriptions by adding the factors leading to the suppliers decoupling social sustainability implementation, where relevant. We looked for evidence of barriers, challenges, and impediments that were limiting adoption. This resulted in thick descriptions of each firm's level of social compliance, institutional pressures, and decoupling factors.

Transcripts from each interview were coded and analyzed using QSR NVivo10 ${ }^{\odot}$, which helped to systematically organize the data and be transparent by providing an audit trail (Fielding and Lee 1998; Bryman and Bell 2007). Using such computer-assisted qualitative data analysis software can enhance a researcher's reflexivity. For example, by using memos, researchers can track the development of their analytical logic and raise their awareness of how they interpreted the data (Woods et al. 2016). After all interviews had been transcribed, the formal coding process began. There was however a degree of overlap between data collection and analysis, which is virtually unavoidable in qualitative research (Pratt 2009). For example, pilot interviews were carried out initially in two of the suppliers. Pilot studies are important as they pre-test research instruments such as the interview schedule; the findings can be used to refine the research questions and generate new themes (Van Teijlingen and Hundley 2001; Bryman and Bell 2007). Interim analysis of the pilot data helped to improve the focus of the research objective, identify possible theoretical lenses, and refine the interview guide.

All of the transcripts were read by the first author and a sample was read by the second author. We looked for patterns based on frequency, commonalities, and differences (Saldaña 2013). A coding frame was developed after discussion, and the transcripts were coded by the first author. Then the second author went through the codes to check for 
consistency, according to our definitions of the institutional pressures faced by suppliers and the decoupling factors. These were then compared and disagreements discussed. The coding frame was changed when new codes emerged and the above process was followed again until consensus was reached on the final list of codes. Such rigorous coding allowed us to develop analytical categories, which were then conceptualized into theoretical dimensions, as described below.

To begin with, a descriptive, working set of codes was produced based on the themes identified from the literature on institutional pressures. In theory building research, such a provisional specification of codes can facilitate analysis and provide stronger empirical grounding for emergent theory if the codes prove to be important in answering the research questions (Eisenhardt 1989; Saldaña 2013). The sources of coercive, mimetic, and normative pressure on each of the suppliers were identified from the cases. Interviewees within each case were cross-referenced to triangulate the data. The pressures exerted on each supplier were analyzed and crosscase analysis was undertaken, with the suppliers organized according to their perceived degree of social sustainability. The pressures were then further analyzed to arrive at a more interpretive level of coding. For example, formal education was initially identified as a normative pressure leading to adoption (level-one code 'NOR-EDU'). But as the analysis proceeded, accounts of normative pressure were seen interpretively as involving elements of education, training, and awareness-building of owners/mid-management and workers. Therefore, the initial descriptive code was elaborated to distinguish between the education of workers ('NOR-EDUWOR') and owners/mid-management ('NOR-EDU-MNG'). The information obtained from interviews was validated by checking documents, focus group findings, and observation notes. Converging perspectives of suppliers and other institutional actors were identified and, where applicable, differences were discussed.

In the second analytical stage, we applied theory building, which enabled us to induce categories of decoupling factors. An initial broad set of codes was first taken from the literature, such as conflict in logics and disparity in socio-economic contexts. Then, analytical categories were inductively derived from the data through an iterative process. At this stage, the interview transcripts were reviewed in detail to detect patterns and regularities. Coding was used to identify the factors leading to decoupling, with data coded as a decoupling factor if it met at least one of the following conditions: (1) it was clearly intended by the supplier as a symbolic action, in that the supplier actively tried to circumvent the buyer's social standards or made cosmetic changes to pass the social audit in response to institutional pressures; (2) it was perceived as a symbolic action by the researchers; and/or (3) there was disconnect between adopted and actual practices due to local circumstances. Through constant comparison and interpretation, we were able to inductively derive seven subcategories of decoupling in the data (Eisenhardt et al. 2016): (1) conflict in suppliers' economic and social logics; (2) preparedness to mock comply by suppliers; (3) overlooking of violations by buyers; (4) adversarial relationships with auditors; (5) lack of supply chain visibility; (6) cultural and socioeconomic disparity with Western incompatible codes of conduct; and (7) lack of government enforcement of the law. The categories were constructed to reflect as many of the nuances in the data as possible.

The evidence that emerged from the data suggested that these decoupling factors could be described according to three theoretical dimensions: firm-related, supply chainrelated, and environment-related factors. For example, we grouped conflict in suppliers' economic and social logics and preparedness to mock comply into firm-related decoupling factors. Similarly, we grouped cultural and socio-economic disparity with Western codes of conduct and a lack of government enforcement of the law together because these factors were related to the institutional environment in which the suppliers were operating. This process of building theory on decoupling factors is illustrated in Fig. 1. The figure identifies key codes from the literature and links them to the more specific codes inductively derived from the data that feed into the three aggregate theoretical dimensions of decoupling.

A key aspect of qualitative data analysis is removing doubt surrounding the reliability and validity of qualitatively produced findings (Miles and Huberman 1994). Hence, multiple steps have been undertaken to ensure reliability and validity, including data triangulation via site visits, document analyses, and multiple interviews (Stake 1995; Bryman 2008; Yin 2009). Finally, cross-case analysis was undertaken to search for patterns, i.e., similarities and differences between the coded categories across the seven suppliers. For example, some categories such as buyer coercive pressure revealed no clear patterns, but others such as normative pressure through the education of workers led to important patterns of within-group similarity and cross-group differences. This systematic analysis of our case data aided in ensuring rigor thereby increasing confidence in our findings. 


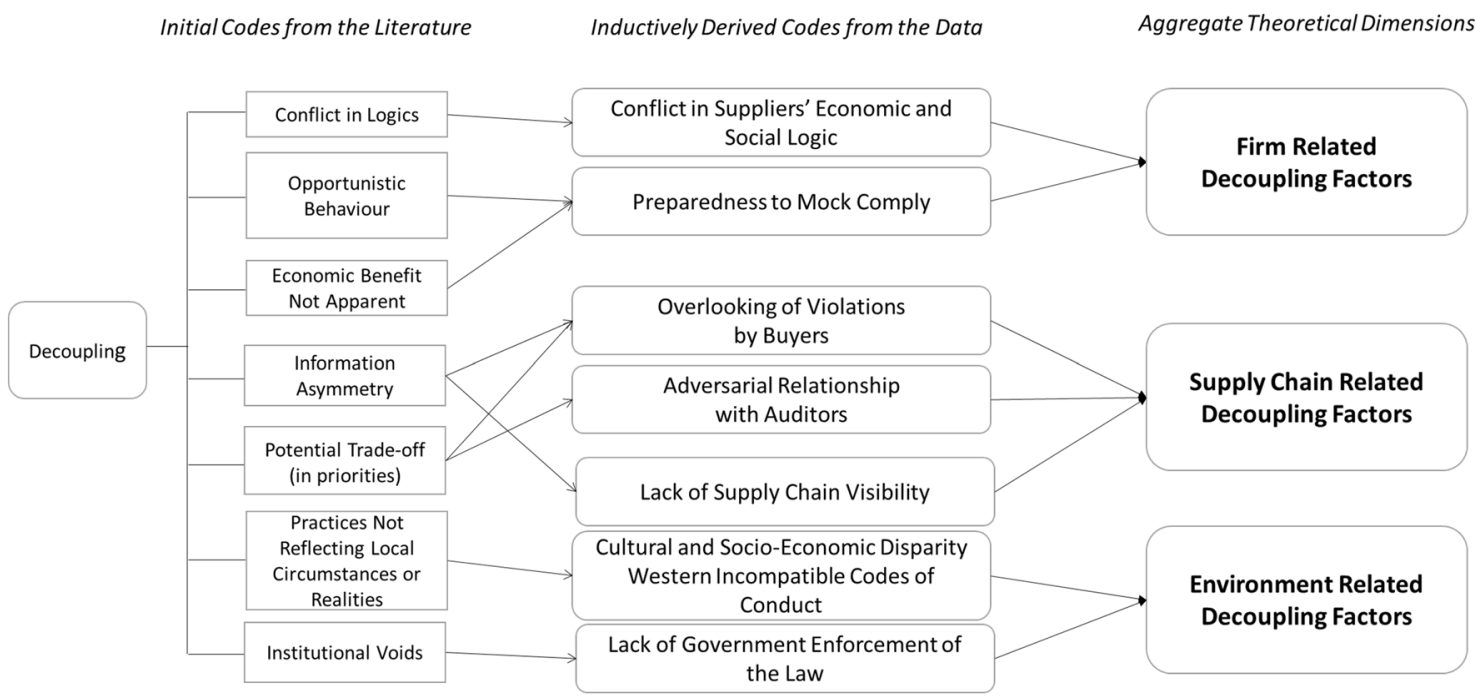

Fig. 1 Decoupling Factors in the Context of Socially Sustainable Practices

\section{Findings Pre-Rana Plaza Collapse: Institutional Pressures and Decoupling Factors}

\section{Cross-Case Analysis of Institutional Pressures Affecting Implementation}

\section{Coercive Pressures on Suppliers}

The string of major industry disasters, even prior to the Rana Plaza collapse, had intensified pressure on buyers, who were in turn able to exert greater coercive pressure on suppliers. As a consequence, the most significant coercive pressure imposed on all seven suppliers was from buyers who made reaching certain social standards an order qualifier. This is shown in Table 3, which shows the frequency of each type of institutional pressure mentioned by the suppliers, and in Table 4, which shows through illustrative quotes the effectiveness of institutional pressures towards the implementation of socially sustainable practices. There was also coercive pressure from the Bangladeshi Apparel Trade Body, which checked on issues like child labor and fire safety. Action was taken against non-compliant factories, with gross violations leading to loss of membership. The Local Chamber of Commerce Director noted however that the trade body's surveillance resources were stretched due to the sector's enormous size: 5700 factories with over 3000 trade body members.

Tables 3 and 4 also contain pressures that were identified as important in the literature but that did not appear important in the cases. For instance, the literature suggests that coercive pressure from other institutional actors like the government, trade unions, and NGOs plays a key role in promoting sustainable supply chain management. Yet our data suggest that these sources were less prominent and often ineffective. For example, although government officials inspected supplier factories, it was alleged that they were often corrupt. Supplier 1's Compliance Manager recounted: "The government labor agency comes to audit every 6 months, but mainly they come for money. They see violations, but if you bribe them, they go away." This reflects the context in which the supplier factories are embedded. Indeed, although it has improved its position somewhat, Bangladesh has been ranked consistently near the bottom (1-15) of the Corruption Perceptions Index for the last 15 years (Transparency International 2016). Therefore, although on the surface the country's labor laws appeared strict, buyers had to take on the responsibility for implementation because these laws were not enforced.

One might expect trade unions to be a key institutional actor at the interface between workers, suppliers, and buyers, yet none of the seven suppliers had an internal trade union. The suppliers suggested that this was because unions become 'politicized.' Rather than looking after workers' welfare, suppliers claimed union leaders call unnecessary strikes and hold owners to ransom. In contrast, during the focus group discussions, the workers revealed that they faced various challenges from management if they wanted to form trade unions. For example, some workers disclosed that they had faced intimidation, lost their job or been forced to resign when they asked about unionization. Similar to trade unions, none of the suppliers reported any coercive pressure from NGOs. Rather, they claimed that NGOs have hidden agendas, and that they sometimes try to incite worker unrest for their own financial gain. Supplier 2's HR Manager stated: "An NGO is blackmailing us for money, or else they will 
Table 4 Institutional pressures on suppliers and their effectiveness (with example quotations)

\begin{tabular}{ll}
\hline Institutional pressure on developing country suppliers & $\begin{array}{l}\text { Effectiveness of pres- } \\
\text { sure on implementa- } \\
\text { tion }\end{array}$
\end{tabular}

Coercive pressures

Buyers

High

Professional trade bodies/associations

Medium

Government

Trade unions/workers

Low

NGOs/rights groups

Low

Mimetic pressures

Competitors (and competition for orders)

High

Workers (and competition for workers)

Medium

Normative pressures

Owners/mid-management

Medium
I think it was forced by the buyers or else social compliance wouldn't have happened. Proactive social responsibility [by suppliers] is very negligible. (Supplier 1, Compliance Manager)

It is because of the buyer pressure. If you are not compliant, the buyers won't give you work. Social compliance is being enforced only because of the buyer. (Supplier 6, HR Manager)

The Apparel Trade Body has monitoring teams who inspect the factories for compliance, such as on child labor. They are very serious about it or else the industry as a whole will be plagued worldwide. The motivation or initiative is from us as all owners are members. They have taken action against faulty factories, such as fines or they lose their membership. (Supplier 1, MD)

If it is left to the government to implement social standards, it will never happen. (Supplier 5, HR Manager)

The labor laws are there but not strictly implemented and you could circumvent them. (Supplier 1, MD)

...the law and order situation in Bangladesh is not conducive to trade unions. (Supplier 2, Compliance Manager)

Within the factory, there are still no trade unions. (Supplier 6, Director)

I feel the NGOs play a very negative role for this industry. They have a hidden agenda and give an image that they care about the workers...they are always vindictive towards the factories...make no mistake that a certain proportion of them are exploiting the workers. (Supplier 3, DMD)

Since there are a lot of factories now and lot more competition, everyone is under pressure to improve [social standards] to attract buyers. (Supplier 6, Director)

Another factor is that now there is more competition amongst the factories. If we are not compliant then the buyer will give the order to someone who is. (Supplier 4, Compliance Manager)

The market has changed tremendously in the last 5 years. Five years ago, there was an abundance of garment workers, but now there has been a massive increase in the number of factories. The social compliance issues are not something only from the buyers' side now. It is also a competitive pressure as other factories are doing them. If a factory now does not pay the workers a proper salary or give them the benefits that they are entitled to, then it will not get any workers as the demand for workers far exceeds the supply. (Supplier 3, DMD)

The owner's educational background, international exposure and willingness plays a part. (Supplier 7, HR Manager)

It was the initiative of our Chairman. He has a Masters in commerce. He is very open and very concerned about sustainability. (Supplier 7, Head of Sustainability)

At the manager level, we have a 3-day orientation program in which there are 2 sessions that are on sustainability. (Supplier 7, Distribution Executive) 
Table 4 (continued)

\begin{tabular}{|c|c|c|}
\hline Institutional pressure on developing country suppliers & $\begin{array}{l}\text { Effectiveness of pres- } \\
\text { sure on implementa- } \\
\text { tion }\end{array}$ & Illustrative quotations \\
\hline Workers & Low & $\begin{array}{l}\text { Internally we give training to the workers. We have a separate } \\
\text { training department who does this. Every worker goes through } \\
\text { an orientation program when they join where we train them } \\
\text { about their rights. We also train our HR personnel called ToT } \\
\text { [Training of Trainers] so that they can train the workers. At the } \\
\text { moment, we have } 39 \text { types of training that is provided to our } \\
\text { employees. (Supplier 7, Head of Sustainability) } \\
\text { Five years ago, the workers didn't even know what is basic salary } \\
\text { or overtime. Now they know everything. (Supplier 3, DMD) }\end{array}$ \\
\hline Professional trade bodies/associations & Medium & $\begin{array}{l}\text { Initially, [the Apparel Trade Body] had consultants who helped } \\
\text { me understand compliance. From time to time, they arrange } \\
\text { training for us. (Supplier 3, HR Manager) } \\
\text { The [Apparel Trade Body] gives training sessions. I have } \\
\text { attended some of them. But this is in collaboration with the } \\
\text { buyers. We were given some materials and posters, which we } \\
\text { have shared in our factory to build awareness. (Supplier } 6 \text { HR } \\
\text { Manager) }\end{array}$ \\
\hline
\end{tabular}

cause worker disturbance in our factory... They work for their own interests - if the factory shuts down, the workers are the losers."

\section{Mimetic Pressures on Suppliers}

In the literature, the discussion regarding mimetic pressure on suppliers is generally related to competition. Our crosscase analysis reinterpreted mimetic pressures on suppliers by distinguishing them into: (i) competition for orders from buyers; and (ii) competition for the limited available skilled labor force. Typically, suppliers copied rival firms to compete for orders, but because there was a shortage of skilled labor, firms were also having to implement social standards to retain workers and were having to improve their social sustainability performance to attract better workers. This mimetic pressure for skilled labor and orders was primarily due to an increase in the number of factories from 3480 in 2000/01 to 5700 in 2011/12 (BGMEA 2016). Specifically in terms of employee retention, workers in both FGDs referred to cases where higher standards in neighboring factories had been used as leverage to pressurize management into providing similar conditions. This mimetic pressure was almost 'enforced' on the suppliers, as explained by the workers from the FGDs: "Workers create awareness amongst themselves and then pressurise the factories to be more compliant" (FGD 2); and "Yes, I will go where I will get better facilities" (FGD 1). These examples illustrate the importance of social conditions to workers and inform where they choose to work. They also demonstrate how, in a market where labor is in shortage, these actors whose voices are rarely heard have a certain degree of power.
From Table 3, it can be seen that Supplier 7 did not report any mimetic pressure, be it due to orders or workers. Since they were the trailblazers in the industry, others were benchmarking against them, i.e., Supplier 7 was the source of mimetic pressure on other suppliers. This placed Supplier 7 in a unique position. They did not have to compete for orders or workers, but they did face negative pressure from poorly performing suppliers. For example, Supplier 7 had implemented a profit-sharing scheme for workers and received significant push-back from their neighboring factories (competitors). NGO1's Operations Director-who collaborated with Supplier 7 on this project—explained: "Sometimes, a factory that wants to improve standards faces resistance from their less compliant neighbors who pressurize the proactive supplier not to give benefits since, if his neighbor implements such practices, then he will be forced to do the same." Thus, negative pressure on proactive suppliers from competitors to be less socially sustainable is a potential barrier to the diffusion of socially sustainable practices.

\section{Normative Pressures on Suppliers}

The level of education and awareness in the institutional field varies according to factors such as age and hierarchical position, and this contributes to shaping attitudes towards social sustainability. Most Bangladeshi factories are familyrun, where the first generation of owners had a low level of education. Similarly, the majority of mid-level managers had no specialized education and learned primarily through experience. Hence, their attitude was often similar to that of the first generation owners. More recently, a second generation had emerged with a higher level of education, often gained from international universities, and with a different 
outlook towards social sustainability. This was a trend that we observed in our sample. For example, the four suppliers rated as having moderate levels of social sustainability had the second generation playing an active role in management, whereas suppliers 1 and 2-with low levels of social sustainability implementation-did not. Supplier 7-the only supplier with a rating of high—was an outlier, i.e., its owner is a first-generation entrepreneur, but he was educated at one of the top universities in Bangladesh and exhibited superior social logic compared to the other owners. For example, Supplier 7 regularly publishes an annual Global Reporting Initiative (GRI) Sustainability Report; is a signatory of the United Nations Global Compact (UNGC), which asks companies to support core values in the areas of human rights, labor standards, etc.; and is a member of the Fair Labor Association (FLA). These initiatives, which go beyond what is required by buyers' social standards, have resulted in Supplier 7 winning numerous prestigious sustainability awards.

At the lower hierarchical levels, there was evidence of limited education being provided by NGOs who made workers aware of labor laws, health and safety protocols, and how to undertake collective bargaining. This however did not translate into a credible source of normative pressure on suppliers. There was also a lack of genuine training of their workers by suppliers. According to workers in FGD2, suppliers only educated them on issues that were in the suppliers' own interest, for example, by educating workers on the minimum notice period and not on severance pay rights. Again, the exception was Supplier 7, which had separate departments that conducted worker orientation programs.
Finally, the Apparel Trade Body served to propagate normative rules about socially sustainable practices. It had created a social compliance department and collaborated with numerous buyers-including Buyer 4 and Buyer 6to make and distribute educational films amongst suppliers for workers and management on fire safety. This initiative, which started before the Tazreen fire that killed more than 100 workers in November 2012, was commended by workers, NGOs, suppliers, and buyers alike.

\section{Cross-Case Analysis of Decoupling Factors}

As we have seen in the previous section, the most significant pressure on suppliers' social sustainability performance came from buyers, who introduced stringent codes of conduct. Many of the suppliers interviewed had successfully become approved suppliers to major international retailers, allowing them to continue to win orders. Nonetheless, problems clearly remained, as was evident from the Tazreen factory fire just 5 months before the Rana Plaza collapse.

In this section, we unbundle the factors leading to decoupling into firm-, supply chain-, and environmentrelated factors. Table 5 shows the types of decoupling factor evident in each supplier while Table 6 provides a description of the decoupling coding categories and illustrates through quotes from suppliers, buyers, and other institutional actors how each decoupling factor was triangulated.

Table 5 Type and frequency of decoupling factors

\begin{tabular}{|c|c|c|c|c|c|c|c|c|c|}
\hline \multirow[t]{3}{*}{ Decoupling factor } & \multirow[t]{3}{*}{ Sub-category } & \multicolumn{7}{|c|}{ Level of social sustainability implementation } & \multirow[t]{3}{*}{ Frequency } \\
\hline & & \multicolumn{2}{|l|}{ Low } & \multicolumn{4}{|l|}{ Moderate } & \multirow{2}{*}{$\begin{array}{l}\text { High } \\
\text { Supplier } 7\end{array}$} & \\
\hline & & Supplier 1 & Supplier 2 & Supplier 3 & Supplier 4 & Supplier 5 & Supplier 6 & & \\
\hline \multirow[t]{2}{*}{ Firm related } & $\begin{array}{l}\text { Conflict in economic } \\
\text { and social logics }\end{array}$ & $\mathrm{Y}$ & $\mathrm{Y}$ & $\mathrm{Y}$ & $\mathrm{Y}$ & $\mathrm{Y}$ & $\mathrm{Y}$ & $\mathrm{N}$ & 6 \\
\hline & $\begin{array}{r}\text { Preparedness to mock } \\
\text { comply by suppliers }\end{array}$ & $\mathrm{Y}$ & $\mathrm{Y}$ & $\mathrm{Y}$ & $\mathrm{Y}$ & $\mathrm{N}$ & $\mathrm{Y}$ & $\mathrm{N}$ & 5 \\
\hline \multirow[t]{3}{*}{ Supply chain related } & $\begin{array}{l}\text { Overlooking of viola- } \\
\text { tions by buyers }\end{array}$ & $\mathrm{Y}$ & $\mathrm{Y}$ & $\mathrm{Y}$ & $\mathrm{Y}$ & $\mathrm{N}$ & $\mathrm{Y}$ & $\mathrm{N}$ & 5 \\
\hline & $\begin{array}{l}\text { Adversarial relation- } \\
\text { ships with auditors }\end{array}$ & $\mathrm{Y}$ & $\mathrm{Y}$ & $\mathrm{Y}$ & $\mathrm{Y}$ & $\mathrm{N}$ & $\mathrm{Y}$ & $\mathrm{N}$ & 5 \\
\hline & $\begin{array}{l}\text { Lack of supply chain } \\
\text { visibility }\end{array}$ & $\mathrm{Y}$ & $\mathrm{Y}$ & $\mathrm{Y}$ & $\mathrm{Y}$ & $\mathrm{Y}$ & $\mathrm{Y}$ & $\mathrm{N}$ & 6 \\
\hline \multirow[t]{2}{*}{ Environment related } & $\begin{array}{l}\text { Cultural and socio- } \\
\text { economic disparity } \\
\text { with Western codes } \\
\text { of conduct }\end{array}$ & $\mathrm{Y}$ & $\mathrm{Y}$ & $\mathrm{Y}$ & $\mathrm{Y}$ & $\mathrm{N}$ & $\mathrm{Y}$ & $\mathrm{N}$ & 5 \\
\hline & $\begin{array}{l}\text { Lack of government } \\
\text { enforcement of the } \\
\text { law }\end{array}$ & $\mathrm{Y}$ & $\mathrm{Y}$ & $\mathrm{Y}$ & $\mathrm{N}$ & $\mathrm{Y}$ & $\mathrm{Y}$ & $\mathrm{N}$ & 5 \\
\hline
\end{tabular}




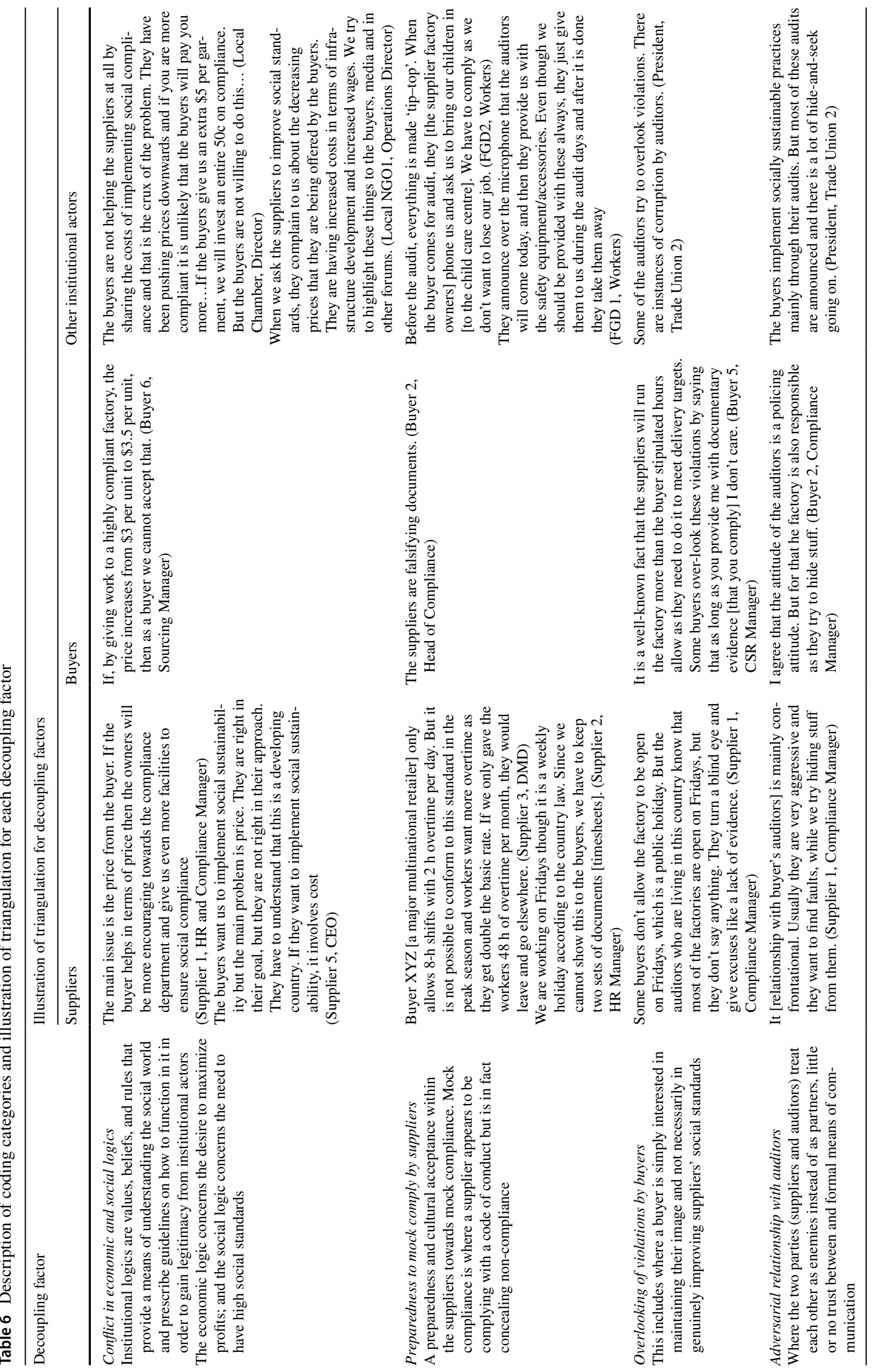




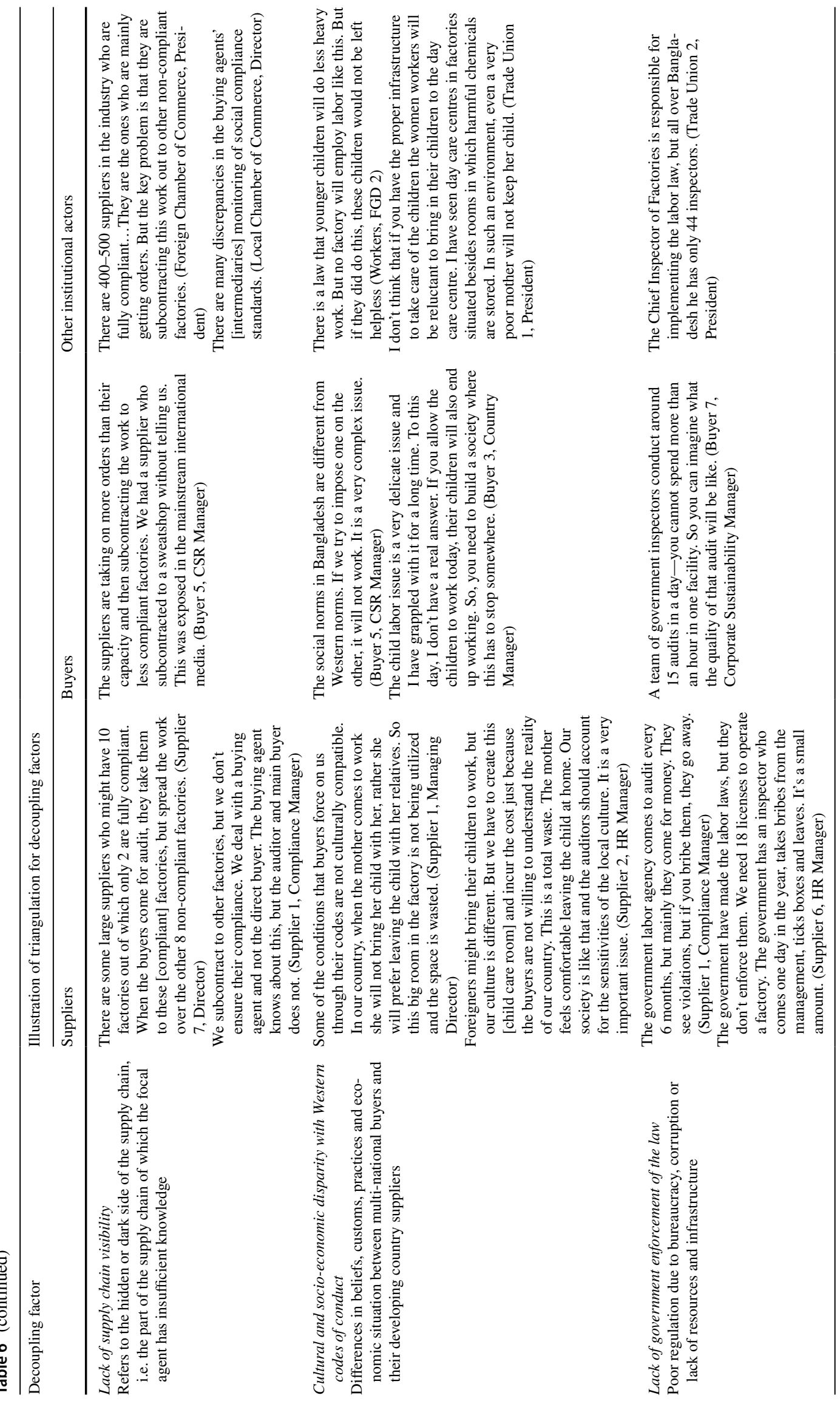




\section{Firm-Related Decoupling Factors}

Conflict in Suppliers' Economic and Social Logic Implementing socially sustainable practices in the Bangladeshi apparel sector involves attempting to elevate the social logic-and the need to improve social standards-in supplier factories where decision making has been largely dictated by the economic logic of maximizing profits. Historically, the economic logic has dominated to such a degree that it has been to the detriment of social (and ecological) conditions (Montabon et al. 2016). Thus, a key cause of decoupling-despite the risks to reputation, credibility, and business-was perceived conflict between the economic and social logics. For example, many suppliers were not willing to make the required investment in genuine implementation because of the short-term impact on profitability and the unwillingness of buyers to share in the costs of implementation. Suppliers also described how buyers appeared to be in conflict themselves-wanting to source from compliant factories but not pay higher prices. Supplier 5's CEO argued: “A compliant factory cannot compete on price with a non-compliant factory... [some] buyers are still buying knowingly from noncompliant factories because of lower prices."

Many suppliers that perceived there to be conflict between the economic and social logics sought out buyers prepared to source from non-compliant factories (e.g., Supplier 1 and 2 ). But this set of buyers was reducing in number over time. Other suppliers (suppliers 3-6) were reluctant adopters that could not see the benefit of social sustainability but were coerced into implementation. These firms were the most likely to decouple or superficially comply. In such suppliers, isomorphism was leading to the formal adoption of socially sustainable practices (as assessed through audits) but not necessarily to their genuine, day-to-day implementation. A minority of suppliers, like Supplier 7, were proactive early adopters who had already begun to build their competitive strategy around social sustainability. Supplier 7's Head of Sustainability described how being socially sustainable was improving the company's reputation and helping to attract more customers, including those focused more on quality than cost. For these firms, the economic and social logics were perceived as being complementary, with socially sustainable practices seen as being good for business (Sroufe et al. 2000).

Preparedness to Mock Comply by Suppliers A second factor within the suppliers that contributed to decoupling was a preparedness or cultural acceptance within the firms to mock comply. Mock compliance is the key manifestation within the cases of decoupling, but this cannot easily by achieved by one or two individuals - it often relies on many actors within the suppliers going along with the charade. Audits against codes of conduct and third-party certifications (on employee wages and benefits, child and forced labor, workplace harassment, working hours and conditions, etc.) could be surprise visits but were usually scheduled, allowing suppliers to prepare and control the audit environment. There are several examples in the data of mock compliance involving various actors within the suppliers. This includes:

- Hiding violations: For example, maintaining multiple timesheets to hide working-hour violations. Fake, compliant timesheets are shown to inspectors while genuine, non-compliant timesheets are used by the payroll department. Suppliers claimed they cannot simultaneously limit overtime and meet tight lead times. They also claimed adhering to overtime limits would contribute to worker migration. Supplier 7's Director explained: “when I capped overtime, I lost 20-30\% of my workers [to competitors who were allowing more overtime so workers could increase their earnings]. So we made a deal with the workers: you can do more overtime but, when the buyer comes, you cannot tell them you do more than 2 h."

- Short term, superficial conformance: For example, complying for audit-day only. This includes only opening the required childcare center, having doctors on site, and supplying safety equipment and uniforms on audit day. Although some buyers attempt surprise audits to stop this practice, Trade Union 2's President explained: “suppliers bribe the auditor's driver. The driver is instructed by the supplier to inform them when the auditors are coming for surprise visits. The corruption has reached such a level!"

- More blatant cheating: For example, supplier representatives taking auditors to their fully compliant factory before spreading orders over their other, non-compliant factories where they can produce more cheaply.

\section{Supply Chain-Related Decoupling Factors}

Overlooking of Violations by Buyers Some interviewees suggested buyers are complicit in mock compliance. One example concerns working-hour violations, with suppliers claiming buyers 'turn a blind-eye.' The Human Resource Managers of suppliers 1 and 2 alleged some auditors are aware-but ignore-the fact that most Bangladeshi factories are open on Fridays despite it being a holiday. Indeed, interviewees from buyers 2, 4, and 5 acknowledged knowing about working-hour violations. They claimed such violations cannot be completely eliminated and that it is better to work with suppliers on these issues rather than to penalize them, as the latter only leads to violations being hidden. Another example concerns cotton from Uzbekistan. This cotton is banned due to the alleged use of children and convicts to pick the cotton, but it was claimed buyers are aware it is still being used. 
Adversarial Relationships with Auditors Another factor contributing to decoupling concerns the actor responsible for the audit and the nature of the relationship between the supplier and the actor. Audits conducted by buyers directly are perceived as being softer than those conducted by third parties that act on behalf of the buyer. The marked difference in perceptions of the two types of audits and auditors contributes to decoupling behavior. While some buyers may overlook certain types of violations, as above, or take a developmental approach to retain good relations with the supplier and gradually improve their social performance, it was claimed that third-party auditors are much stricter meaning suppliers try to hide violations from them. The suppliers perceived the third-party auditors as being driven by their own economic incentives, failing factories so they could return a second time and receive a second fee from the buyer. The MD of Supplier 2 claimed that third-party auditors 'terrorise the factories and do policing duty' and have a preconceived notion that the factory is being very unfair and unjust towards the workers, whereas the buyer's own auditors "talk very frankly" and "behave like partners." Similarly, the HR Manager of Supplier 3 explained that the buyers' auditors are changing their attitude from "policing duty" to "factory development."

Lack of Supply Chain Visibility Extended global supply chains that make it difficult to maintain traceability create a context in which decoupling can develop. It was claimed the use of intermediaries that procure on a buyer's behalf contribute to decoupling. They often source from cheaper, noncompliant suppliers to increase their profit share without informing the buyer. Meanwhile, suppliers may subcontract work to other, non-compliant factories without the buyer's knowledge. Supplier 7's Director explained: "Sometimes, we get greedy and take on more orders than our capacity. We then have to outsource to less compliant factories who have lower overhead costs ... Some factories-by subcontracting work to other, smaller factories-keep their hands clean but dirty those of others." Many buyers are aware that social sustainability needs diffusing further upstream yet the focus of audits is often exclusively on the immediate supplier. Those that have tried to evaluate tier-two suppliers or investigate the use of subcontracting have been obstructed. Indeed, Supplier 2's Human Resource Manager admitted: "we don't want them to go and check the compliance of our suppliers [second tier] as it will create extra complications."

\section{Environment-Related Decoupling Factors}

Cultural and Socio-Economic Disparity with Western Standards Codes of conduct are typically based on Western experiences and do not reflect the cultural and socio-economic environment of a developing country like Bangladesh. This contributes to the decoupling phenomenon-some factories will mock comply simply to match up to requirements that go against local practices. This results, for example, in auditday charades involving the use of childcare centers, which are not culturally accepted; and in falsifying timesheets so suppliers can provide workers with higher rate overtime. But while it has been alleged buyers have ignored 'minor' violations, they will not compromise on child labor. This is undeniably the right course of action when examining the apparel industry in isolation, but the issue is more complex when Bangladesh is considered as a whole. Our data suggest that child labor has been displaced from garment factories to other, less regulated and more hazardous industries like construction. Supplier 3's Managing Director stated: “There is child labor in almost all other industries in Bangladesh. The children were not doing hard labor in garment factories, but now it has been banned, they are going into more dangerous professions, which are not monitored." Without a coordinated response-which is likely to require government involvement-it is questionable whether this aspect of a code of conduct actually reduces child exploitation.

Lack of Government Enforcement of the Law Finally, our data previously demonstrated that corruption is rife in the government agencies responsible for enforcing social standards. Further, it has been alleged that the government provides little support for social sustainability initiatives, perhaps due to its limited law enforcement resources. The unusual institutional environment of a developing country has implications for the diffusion of social sustainability. Since buyers do not receive the same level of government support as in a developed country, there is scope for decoupling.

\section{Findings Post-Rana Plaza Collapse: Theorizing How Change in Pressure Affects Decoupling}

"A jolt has to happen for Bangladesh to take this [social sustainability] seriously”. [Before Rana Plaza Disaster]

"I think Rana Plaza was the jolt that I told you about before ... a lot of improvements will now happen in Bangladesh". [After Rana Plaza Disaster]

Buyer 3 Country Manager

What would be the state of the apparel industry in Bangladesh if the Rana Plaza disaster had not occurred? Our study would have ended at the previous section after the identification of the institutional pressures and decoupling factors. Yet the above insightful and eerie prophecy from the Country Manager of Buyer 3 demonstrates that a shock 
of this magnitude was almost inevitable and that it was sadly required as a catalyst to create a sudden step-change in attitudes towards implementing socially sustainable practices. In this section, we use data collected after the collapse (see Table 2) to show how the institutional pressures on Bangladeshi suppliers have changed and how this has affected the implementation of social sustainability.

\section{Change in Coercive Pressures and the Effect on Decoupling}

After the Rana Plaza collapse, a new phenomenon emerged-major collective action led by groups of buyers. Two groups in particular were formed. Accord consisted of over 160 mainly European buyers that now worked together with global and local trade unions, supported by NGOs. The other group, Alliance, brought together 26 North American apparel brands and trade associations. The two groups use similar standards to conduct fire, electrical, and structural safety audits of suppliers, while Accord has also pledged to contribute towards the costs of improvements. Three out of the four suppliers interviewed after the collapse fell under the governance of at least one of these groups. The groups started to make their audit reports publicly available, placing greater coercive pressure on suppliers-essentially naming and shaming non-compliant factories.

Collective action meant the repercussions of failing an audit were severe: not just one, but a whole group of buyers would no longer source from a supplier. Factories that did not meet the standards were effectively being shut down. Supplier 3's DMD conceded: "adhering to the new standards is a matter of survival. If you do not pass, either you lose the business or the worst case scenario is you are forced to shut down." Similarly, Supplier 6's Director explained: "We have no option but to make costly changes. It might cost us around $\$ 350,000 \ldots$ but it is a requirement I have to fulfil." Such collective, coercive pressure by buyers served to make social and economic logics in developing country suppliers more closely connected. Thus, social logic was heightened, even if the economic logic continued to dominate. These findings extend previous research on how powerful buyers can promulgate change in suppliers (Benton and Maloni 2005; Yu 2008; Marshall et al. 2016) and lead to our first proposition:

Proposition 1 Collective coercive pressure from horizontal collaboration between buyers (including more transparent group audit-reporting) reduces the conflict in social and economic logic, thus lowering the propensity of developing country suppliers to decouple and leading to a higher level of social sustainability implementation.
Collective coercive buyer pressure also helped to mitigate decoupling caused by the lack of law enforcement that previously undermined implementation. Supplier 3's DMD explained: "The biggest change was brought about by Alliance and Accord. If the buyers, suppliers, or the government for that matter, wanted to do this individually through their own inspections they would never have been able to do what these two organizations have done." In effect, the two groups of buyers were playing a quasi-governmental role since the government was unable or unwilling to fulfil this function. This leads to the following proposition:

Proposition 2 Collective coercive pressure from horizontal collaboration between buyers that effectively replaces government regulation reduces the propensity of developing country suppliers to decouple, leading to a higher level of social sustainability implementation.

Suppliers with a low level of social sustainability implementation (e.g., Supplier 1) appeared to be unable to overcome the apparent conflict between the social and economic logics, even after the disaster. Further, they did not possess the capabilities to make the more expensive improvements now demanded collectively by buyers, who were also trying to reduce their supplier bases and levels of risk exposure by procuring from (fewer) larger and more compliant suppliers only. The number of suppliers reduced from 5876 in 2012/2013 to 4328 in 2015/2016 (BGMEA 2016). In fact, the Director of Supplier 1 disclosed to us that they had decided to end their business as a direct result of their inability to cope with increased buyer requirements after Rana Plaza. She stated: "Rana Plaza had a direct impact on our decision of shutting down the business. We do not have our own building [it is rented] and some of the compliance issues like having extra staircases cannot be solved. So we will fail every audit. They require 50,000 gallons of water reserve, we don't have this. Unless we have our own building and are willing to make this kind of investment [for social compliance], our main buyer will not continue with us...After Rana they [buyers] want us to be more socially compliant, but they are not willing to pay us for it...The trend will be that only the big players who can bear the cost of increased compliance requirements will survive and the smaller suppliers will shut down" This example shows that Supplier 1 was not able to survive in the industry because of its unwillingness to meet the greater social sustainability expectations of buyers, and this unwillingness was largely due to perceived conflict with its more dominant economic logic. This leads to the following proposition:

Proposition 3 Only those suppliers that are able to develop complementary economic and social logics will cultivate the capabilities that are necessary to respond to collective 
coercive pressure from buyers and improve their chances of long-term survival.

\section{Change in Mimetic Pressure and the Effect on Decoupling}

Our analysis of the case data before the collapse of Rana Plaza showed that one of the reasons for firm-related decoupling is mock compliance. This critical finding is connected to the larger literature stream on the effectiveness (or lack thereof) of codes of conduct and, in particular, the audits that many customers require (Huq et al. 2014; Egels-Zandén and Lindholm 2015). However, after the Rana Plaza disaster, suppliers were incentivized to reach minimum acceptable compliance standards. One of the reasons was amplified mimetic pressure through increased competition for orders as buyers backed away from procuring from less compliant suppliers, and some buyers exited the Bangladesh market altogether. Thus, orders became harder to secure, and this made the risks of mock compliance too great for the reward. This leads to the following proposition:

Proposition 4 Heightened mimetic pressure from an increase in competition for orders reduces the propensity of suppliers to decouple via mock compliance and leads to a higher level of social sustainability implementation.

\section{Change in Normative Pressure and the Effect on Decoupling}

After the Rana Plaza disaster, buyers (including via coalitions/horizontal collaboration) invested in the education and training of their own staff in Bangladesh and in that of their suppliers at all levels-owners, middle managers, and workers. For example, buyers used external consultants to train and develop supplier fire and building safety capabilities. Buyer 2's Compliance Manager explained: "my firm flew me to the UK to attend training programmes on fire safety. We are now providing our suppliers with expert help." Meanwhile, Supplier 3's DMD described how buyer groups were educating and training his workers in stages. They first came with tablet computers and gave workers multiple choice questions to test their level of fire safety knowledge then shared the results with the management. He explained: "They asked the workers what they will do in case of a fire. Most answered that they would hide under the table! ... We were shocked as our HR department was 'training' them. We found that our training was not at all effective and it was not communicated well." As a result, Supplier 3 sent around $20 \%$ of their workforce for fire safety training before becoming certified fire fighters. Through education and training, these workers became more aware of social compliance issues and were able to exert normative pressure on the suppliers. Buyer groups also tested and trained midlevel managers, nurses, and electricians. But, according to the DMD of Supplier 3, the most important change was the education of the owners, which infused in them the need to have higher social standards. These measures decreased conflict between the social and economic logics in suppliers. This discussion leads to our next proposition.

Proposition 5 Normative pressure via education and training from buyers causes a logic shift—heightening the social logic and reducing the dominance of the economic logicthus lowering the propensity to decouple and leading to a higher level of social sustainability implementation.

Compliant factories, particularly proactive, early adopters that had built their competitive strategy around social sustainability now began to be rewarded. Indeed, once a supplier had invested in being socially responsible, it began to reap rewards through worker productivity and customer orders, which led to an enhanced reputation, attracting new customers, and so on. In particular, Supplier 7 had the most heightened social logic in our sample, winning numerous awards and paying its workers $20 \%$ above the industry average. Supplier 7 understood that the economic and social ideologies could complement each other in the long term and found improving standards actually increased productivity via worker retention and reduced absenteeism. Being socially sustainable was improving the company's reputation and helping to attract more and better customers. In fact, the collapse of the Rana Plaza led to an influx of orders from like-minded buyers who not only offered better prices to compliant factories but also involved their suppliers in community projects, collaborating with various NGOs and donor agencies. This kind of stakeholder collaboration created extra normative pressure on such proactive suppliers. This discussion leads to our final proposition:

Proposition 6 When the economic and social logics are perceived to be complementary, suppliers gain first-mover advantage to work with more socially sustainable buyers resulting in a virtuous cycle, whereby normative pressure continues to increase over time and thus reinforce social sustainability implementation.

\section{Discussion and Conclusions}

With this study, we aimed to contribute to the emergent literature on the social aspects of ethical sourcing (Zorzini et al. 2015; Kim et al. 2016) through an empirical exploration of how the institutional pressures imposed on developing country suppliers affect the implementation of socially sustainable practices. So far, scholars have paid only limited 
attention to the supplier's perspective, especially in developing countries such as Bangladesh (Yawar and Seuring 2015; Zorzini et al. 2015). While we are not the first to have argued that the institutional context of a developing country means that actors experience different pressures to those in a developed country (Zhu and Sarkis 2007; Sancha et al. 2015), to the best of our knowledge, ours is the first attempt to investigate the under-researched developing country supplier's viewpoint in such detail. Our analysis illustrates subtle differences in the institutional pressures faced by developing country suppliers-for example, highlighting the mixed role played by NGOs, which have been viewed as entirely positive contributors to social performance in prior literature; the phenomenon of 'enforced mimetic pressure' whereby competition for workers also acts as an important source of mimetic pressure; a novel and emergent form of negative mimetic pressure exerted on proactive suppliers by unethical competitors to be less socially sustainable; and a new insight into normative pressure by highlighting the differences between the level of education and training of firstand second-generation factory owners.

In a wider theoretical context, our analysis contributes to an enhanced understanding of the factors leading to the decoupling of ethical practices in challenging institutional contexts. One of our fundamental theoretical contributions is to have shown, through our set of propositions, how changes in various forms of institutional pressure can help to reduce developing country suppliers' propensity to decouple, improving the level of implementation of socially sustainable practices. Thus, the work contributes to the broader theme of implementing ethical practices in challenging institutional settings and may be of particular interest to firms looking to bring about change and reform in distant suppliers that are spatially and culturally far removed. We now discuss in more detail how the key contributions of this study advance research on the social dimension of ethical sourcing.

Our study extends work on implementing ethical practices in developing country suppliers (Ehrgott et al. 2011; Huq et al. 2014) by illustrating the multi-level effects of institutional pressures on developing country suppliers to implement socially sustainable practices. A limited number of papers have recently explored social issues in supply chain management. For example, Huq et al. (2014) investigated buyer-supplier relationships through the Transaction Cost Economics (TCE) lens to understand the enablers and barriers of implementing social sustainability in developing country suppliers. The authors' analysis provided insights into the type of supply chain governance mechanism required when transaction costs are high to bring about improvements in social sustainability. Further, it highlighted the need for buyers to extend their reach beyond first-tier suppliers by incorporating second and third-tier suppliers in the implementation process. Huq et al. (2014) also underlined the importance of Western buyers and developing country suppliers extending the scope of their activities to actively consider the roles of workers and other institutional actors, including trade unions, NGOs, and professional trade bodies, in order to develop a more comprehensive understanding of the disconnect between the formal adoption of socially sustainable practices and actual implementation.

Institutional theory has provided us with a set of useful constructs for making sense of data from multiple (more than two) actors, whereas TCE mainly focuses on the direct and indirect costs of managing relationships between partners. Further, institutional theory has enabled us to understand how the forces that exist both within the buyer-supplier dyad and in the wider, external environment influence implementation. The main coercive pressure exerted on suppliers to implement socially sustainable practices was from buyers. Buyer pressure was similarly the most important driver of social reform in earlier studies (Yu 2008; Marshall et al. 2016). The importance of this pressure varied depending on the attributes of the suppliers, who either proactively pursued new practices (Supplier 7) or reluctantly adopted required practices (e.g., Supplier 1). This finding corresponds to an earlier study by Sroufe et al. (2000) on adopting environmentally responsible manufacturing practices, which highlighted how firms influenced by costs found it difficult to bridge the gap (or chasm) to early adopters who were influenced predominantly by a corporate sustainability culture. Meanwhile, the mixed role played by NGOs-perceived by buyers as an important collaborative partner, but distrusted by suppliers - contrasts prior literature, which has offered unanimous support for their part in social sustainability implementation (Maignan et al. 2002; Walker and Jones 2012). Further, our findings on the (limited) coercive role played by government go beyond the extant literature (Lim and Phillips 2008; Yu 2008; Lee and Kim 2009) by highlighting how law enforcement can be undermined by alleged corruption and insufficient 'policing' resources. This leaves scope for opportunism and means buyers must continue to take on the main responsibility, thereby thrusting them into an increasingly politicized role.

In addition to coercive pressure, mimetic pressures were also felt by suppliers in our study. While other studies have highlighted that competition for orders leads to higher levels of implementing ethical practices (Yu 2008; ParkPoaps and Rees 2010), we also identified that competition for labor acts as an important source of mimetic pressure when there is a shortage of skilled workers. Further, we shed light on a unique form of negative mimetic pressure exerted on proactive suppliers by unethical competitors to be less socially sustainable, and also 'enforced' mimetic pressure exerted on suppliers by workers who demand better standards. Finally, it was found that normative 
pressure to comply largely builds through greater education and training of second-generation factory owners, with related knock-on effects, e.g., once a firm becomes more socially sustainable, the rewards can follow in terms of an enhanced reputation and new customers. This creates a virtuous cycle, steadily increasing the level of social sustainability implementation.

Our focus on the decoupling phenomenon has identified firm-, supply chain-, and environment-related factors that lead to a disconnect between the formal compliance structures apparently adopted by suppliers and the genuine implementation of socially sustainable practices. At the firm level, although many suppliers had successfully passed social audits, there was evidence of mock compliance. Previous studies have attributed this kind of behavior to the inadequacies of social auditing (Barrientos and Smith 2007), e.g., the failure of auditors to detect less visible issues such as freedom of association as compared to occupational safety (Anner 2012). A similar concept has been put forward in relation to environmental sustainability-that of green washing (Walker et al. 2008). But unlike previous studies (Huq et al. 2014), we unpack the mock compliance phenomena into its component elements of hiding violations, short-term superficial conformance, and blatant cheating. We have also obtained further insights into the firm-related factors that contribute to decoupling. For example, when the economic and social logics are perceived to be in conflict, the economic logic generally dominates and undermines implementation. Suppliers may be unwilling to make social improvements that increase costs, sometimes even when coerced into doing so, and they may actually prioritize economic performance to the detriment of social conditions. When these two logics are viewed as complementary, the implementation of socially sustainable practices appears much more likely to succeed. Sometimes, the supplier sees the complementarity of the logics after being coerced into implementation but more likely this is achieved through education and training. Thus, there is interplay between the institutional pressures and institutional logics.

In a recent study, Carter et al. (2015) highlighted the opportunities available to develop and refine the dimensions of the supply chain, including its visible horizon, i.e., the part of the supply chain over which the focal firm has sufficient knowledge. In line with this, we provide insights into how not just traditional second-tier suppliers but also unauthorized sub-contractors are beyond the visible horizon of focal firms. This potential 'dark side' of the supply chain - characterized by poor visibility — can hamper implementation efforts. Therefore, when sourcing from developing countries, it is important to be aware of such supply chain-related decoupling factors. Our analysis has further shown that environment-related factors like a lack of law enforcement, due to the alleged widespread corruption of government inspectors, coupled with the government's limited resources, also contribute to decoupling.

By studying such an extreme example of social sustainability implementation and failure, we claim to have been able to generate more transparent insights (Eisenhardt 1989) while the richness of our longitudinal research has helped us provide details of how the core dynamics of the phenomenon played out over time (Siggelkow 2007). As it is such a topical issue, the collapse of the Rana Plaza has motivated various other studies relating to socially sustainable practices in the supply chain. For example, it has been studied empirically through primary case data by Huq et al. (2016) who explored the capabilities that buyers and suppliers can develop for social management (monitoring/auditing, collaboration, and innovation). But the authors did not examine in detail what motivates suppliers to adopt these capabilities or why they get detached from the ground reality. Meanwhile, Jacobs and Singhal (2017) used secondary data to conduct an event study on the effect of the Rana Plaza disaster on shareholder wealth and Plambeck and Taylor (2015) showed through modeling how a buyer might motivate a supplier to increase its responsibility efforts to avoid such a social failure. Our research expands this stream of research e.g., by illuminating how horizontal collaboration and collective action by groups of buyers intensifies coercive pressure on suppliers by increasing the consequences of non-compliance—and this serves to address decoupling.

\section{Implications for Practice}

When poor social standards are uncovered in the supply chain, they become intimately associated with a retailer's products and brand. Social sustainability, therefore, becomes an important aspect of global supplier selection and development. Buyers looking to improve the social sustainability of their supply chains may need to use a combination of carrot and stick. Penalties for non-compliance, rigorous (unscheduled) audits, and collective action through collaborative groups of buyers have all been useful practices for improving implementation levels (stick). But, equally, it can be important to build mutually beneficial and trusting relationships with suppliers, to reward the most compliant factories, to share in the costs of implementation, and to demonstrate a long-term commitment to sourcing from a developing country (carrot).

It is also important to anticipate any decoupling behavior by suppliers and consider how it can be detected and further restricted or avoided. This may involve revisiting codes of conduct and fostering a culture of openness, where the aim is that a supplier does not hide violations but rather works with a buyer to reach compliance. Global sourcing managers also need to be aware of the inefficient institutional environments 
of developing countries like Bangladesh and be equipped to contend with the lack of policing resources and regulatory enforcement. They must be prepared to invest in education and training - particularly that of middle managers and workers-if practices are to be successfully implemented. Education and training may help, for example, to overcome perceived conflict between the economic and social priorities rather than waiting for this to be triggered by another tragic industry event.

Other institutional actors must also play their part in improving conditions and reducing the risk of further tragedies. For example, we have highlighted the need for NGOs and trade unions to build trust with suppliers, and for the industry's trade body to take on a more prominent role in disseminating information and driving change. Government policy makers must also be encouraged to invest more resources in ensuring labor laws are enforced.

\section{Limitations and Future Research}

This study has focused entirely on institutional actors in Bangladesh. It could therefore be connected right through the global supply chain to retail headquarters and end-consumers in North America and Europe. The set of institutional actors studied in Bangladesh is also incomplete. In particular, the work could be extended to include tier-two suppliers, subcontractors, intermediaries, and third-party auditors. It would also be interesting to study how firm size affects homogeneity in terms of the implementation of socially sustainable practices in future research. We further argue that an insightful strand of future research could be to explore how collective pressure from horizontal collaboration between buyers can be enabled. For example, non-traditional supply chain actors such as NGOs may play a significant role in building networks of collaborative partnerships between buyers, suppliers, NGOs, donor agencies, and trade bodies; and may bring together buyers that would normally compete with one another, putting aside their competitive agenda to collaboratively tackle an important industry-wide problem.

The Rana Plaza disaster was an incredibly tragic and unfortunate antecedent of improved sustainability in many Bangladeshi factories-it accelerated the implementation of socially sustainable practices. Given that cultural and socioeconomic disparity with Western codes of conduct was one of the main decoupling factors, it is argued that there is now a need to develop a global compliance structure for Western brands that can be rolled out across all countries and industries. This would seek to ensure certain minimum social standards are upheld wherever sourcing takes place. It is particularly imperative given the phenomenon of sourcing migration across developing countries in search of lower labor costs. For example, Chinese firms are now effectively acting as sourcing agents for Western brands like Guess, Levi's, and H\&M, and turning countries like Ethiopia into the latest fast fashion 'factory' (Bloomberg 2018). There is a significant risk that these new sourcing locations will fail to learn from history. It is therefore vital that changes mirroring those taking place in Bangladesh are achieved in these institutional contexts without being prompted by another tragedy.

Finally, further motivation for implementation could be generated by quantifying the impact of social reform on overall economic performance. For example, this could be achieved via analytical modeling of buyers' strategies to improve sustainability performance through horizontal collaboration. Case studies deliberately investigating discontinuation of social certifications (e.g., SA8000, ISO 24000) could also be very valuable for understanding conditions that prompt organizations to abandon long-term sustainability goals.

\section{Compliance with Ethical Standards}

Conflict of interest The authors declare that they have no conflict of interest.

Open Access This article is distributed under the terms of the Creative Commons Attribution 4.0 International License (http://creativeco mmons.org/licenses/by/4.0/), which permits unrestricted use, distribution, and reproduction in any medium, provided you give appropriate credit to the original author(s) and the source, provide a link to the Creative Commons license, and indicate if changes were made.

\section{References}

Ahi, P., \& Searcy, C. (2013). A comparative literature analysis of definitions for green and sustainable supply chain management. Journal of Cleaner Production, 52, 329-341.

Anner, M. (2012). Corporate social responsibility and freedom of association rights: The precarious quest for legitimacy and control in global supply chains. Politics \& Society, 40(4), 609-644. https:// doi.org/10.1177/0032329212460983.

Awaysheh, A., \& Klassen, R. D. (2010). The impact of supply chain structure on the use of supplier socially responsible practices. International Journal of Operations \& Production Management, 30(12), 1246-1268.

Baden, D. A., Harwood, I. A., \& Woodward, D. G. (2009). The effect of buyer pressure on suppliers in SMEs to demonstrate CSR practices: An added incentive or counter productive? European Management Journal, 27(6), 429-441.

Barnett, M. L., Darnall, N., \& Husted, B. W. (2015). Sustainability strategy in constrained economic times. Long Range Planning, 48(2), 63-68. https://doi.org/10.1016/j.lrp.2014.07.001.

Barratt, M., Choi, T. Y., \& Li, M. (2011). Qualitative case studies in operations management: Trends, research outcomes, and future research implications. Journal of Operations Management, 29(4), 329-342.

Barrientos, S., \& Smith, S. (2007). Do workers benefit from ethical trade? Assessing codes of labour practice in global production systems. Third World Quarterly, 28(4), 713-729. https://doi. org/10.1080/01436590701336580. 
BBC. (2013). Bangladesh garment industry looks to revive image. Retrieved October 2, 2013, from http://www.bbc.co.uk/news/ business-21007699.

BBC. (2014). Bangladesh fire factory owners surrender. Retrieved July 25, 2014, from http://www.bbc.co.uk/news/world-asia-26106490.

Benton, W., \& Maloni, M. (2005). The influence of power driven buyer/seller relationships on supply chain satisfaction. Journal of Operations Management, 23(1), 1-22.

BGMEA. (2016). Trade information. Retrieved October 27, 2016, from http://bgmea.com.bd/home/pages/TradeInformation.

Bhakoo, V., \& Choi, T. (2013). The iron cage exposed: Institutional pressures and heterogeneity across the healthcare supply chain. Journal of Operations Management, 31(6), 432-449. https:// doi.org/10.1016/j.jom.2013.07.016.

Blome, C., \& Paulraj, A. (2013). Ethical climate and purchasing social responsibility: A benevolence focus. Journal of Business Ethics, 116(3), 567-585.

Bloomberg. (2012). Wal-mart, sears must put out factory fires in Bangladesh. Retrieved October 2, 2013, from http://www. bloomberg.com/news/2012-12-02/wal-mart-sears-must-putout-fires-in-bangladesh-factories-view.html.

Bloomberg. (2018). China is turning Ethiopia into a giant fastfashion factory. Retrieved March 28, 2018, from https://www. bloomberg.com/news/features/2018-03-02/china-is-turningethiopia-into-a-giant-fast-fashion-factory.

Boxenbaum, E., \& Jonsson, S. (2008). Isomorphism, diffusion and decoupling. In C. O. Greenwood, R. Suddaby \& K. Sahlin (Eds.), The SAGE handbook of organizational institutionalism (pp. 78-98). London: SAGE Publications Ltd.

Bruntland, G. (1987). Our common future: The world commission on environment and development. Oxford: Oxford University Press.

Bryman, A. (2008). Social research methods. Oxford: Oxford University Press.

Bryman, A., \& Bell, E. (2007). Business research methods. Oxford: Oxford University Press.

Campbell, J. L. (2007). Why would corporations behave in socially responsible ways? An institutional theory of corporate social responsibility. Academy of Management Review, 32(3), 946-967.

Carter, C. R., \& Rogers, D. S. (2008). A framework of sustainable supply chain management: Moving toward new theory. International Journal of Physical Distribution \& Logistics Management, 38(5), 360-387.

Carter, C. R., Rogers, D. S., \& Choi, T. Y. (2015). Toward the theory of the supply chain. Journal of Supply Chain Management, 51(2), 89-97.

Ciliberti, F., de Groot, G., de Haan, J., \& Pontrandolfo, P. (2009). Codes to coordinate supply chains: SMEs' experiences with SA8000. Supply Chain Management: An International Journal, 14(2), 117-127. https://doi.org/10.1108/13598540910941984.

CNN. (2013). Inside a Bangladesh garment factory that plays by the rules. Retrieved August 17, 2014, from http://edition.cnn. com/2013/05/20/world/asia/bangladesh-inside-garment-factory/.

Crilly, D., Zollo, M., \& Hansen, M. T. (2012). Faking it or muddling through? Understanding decoupling in response to stakeholder pressures. Academy of Management Journal, 55(6), 1429-1448. https://doi.org/10.5465/ami.2010.0697.

DiMaggio, P. J., \& Powell, W. W. (1983). The iron cage revisited: Institutional isomorphism and collective rationality in organizational fields. American Sociological Review, 48(2), 147-160.

Economist (2013). After the Dhaka factory collapse, foreign clothing firms are under pressure to improve working conditions at Bangladeshi suppliers - or to go elsewhere. Retrieved October 3, 2013, form http://www.economist.com/news/business/21577 078-after-dhaka-factory-collapse-foreign-clothing-firms-areunder-pressure-improve-working.

Edmondson, A. C., \& McManus, S. E. (2007). Methodological fit in management field research. Academy of Management Review, 32(4), 1246-1264.

Egels-Zandén, N., \& Lindholm, H. (2015). Do codes of conduct improve worker rights in supply chains? A study of Fair Wear Foundation. Journal of Cleaner Production, 107(Supplement C), 31-40. https://doi.org/10.1016/j.jclepro.2014.08.096.

Ehrgott, M., Reimann, F., Kaufmann, L., \& Carter, C. R. (2011). Social sustainability in selecting emerging economy suppliers. Journal of Business Ethics, 98(1), 99-119.

Eisenhardt, K. M. (1988). Agency-and institutional-theory explanations: The case of retail sales compensation. Academy of Management Journal, 31(3), 488-511.

Eisenhardt, K. M. (1989). Building theories from case study research. Academy of Management Review, 14(4), 532-550.

Eisenhardt, K. M., \& Graebner, M. E. (2007). Theory building from cases: Opportunities and challenges. Academy of Management Journal, 50(1), 25-32. https://doi.org/10.5465/amj.2007.24160 888.

Eisenhardt, K. M., Graebner, M. E., \& Sonenshein, S. (2016). Grand challenges and inductive methods: Rigor without rigor mortis. Academy of Management Journal, 59(4), 1113-1123.

Elkington, J. (1998). Partnerships from cannibals with forks: The triple bottom line of 21 st century business. Environmental Quality Management, 8(1), 37-51.

Eriksson, D., \& Svensson, G. (2016). The process of responsibility, decoupling point, and disengagement of moral and social responsibility in supply chains: Empirical findings and prescriptive thoughts. Journal of Business Ethics, 134(2), 281298. https://doi.org/10.1007/s10551-014-2429-8.

Fielding, N. G., \& Lee, R. M. (1998). Computer analysis and qualitative research. London: Sage.

Friedland, R., \& Alford, R. (1991). Bringing society back in: Symbols, practices and institutional contradictions. In W. Powell \& P. Dimaggio (Eds.), The new institutionalism in organizational analysis (pp. 232-263). Chicago: University Of Chicago Press.

Gattiker, T. F., \& Carter, C. R. (2010). Understanding project champions' ability to gain intra-organizational commitment for environmental projects. Journal of Operations Management, 28(1), 72-85.

Gimenez, C., \& Tachizawa, E. M. (2012). Extending sustainability to suppliers: A systematic literature review. Supply Chain Management: An International Journal, 17(5), 531-543.

Gold, S., Seuring, S., \& Beske, P. (2010). Sustainable supply chain management and inter-organizational resources: A literature review. Corporate Social Responsibility and Environmental Management, 17(4), 230-245. https://doi.org/10.1002/csr.207.

Greenwood, R., Raynard, M., Kodeih, F., Micelotta, E. R., \& Lounsbury, M. (2011). Institutional complexity and organizational responses. Academy of Management Annals, 5(1), 317-371. https://doi.org/10.1080/19416520.2011.590299.

Grewal, R., \& Dharwadkar, R. (2002). The role of the institutional environment in marketing channels. Journal of Marketing, 66(3), 82-97.

Guardian (2013). Bangladeshi factory deaths spark action among high-street clothing chains. Retrieved June 29, 2013, from http://www.guardian.co.uk/world/2013/jun/23/rana-plaza-facto ry-disaster-bangladesh-primark.

Gugler, P., \& Shi, J. (2009). Corporate social responsibility for developing country multinational corporations: Lost war in pertaining global competitiveness? Journal of Business Ethics, 87(1), 3-24. https://doi.org/10.1007/s10551-008-9801-5.

Haffar, M., \& Searcy, C. (2017). Classification of trade-offs encountered in the practice of corporate sustainability. Journal of 
Business Ethics, 140(3), 495-522. https://doi.org/10.1007/ s10551-015-2678-1.

Hoffman, A. J. (2001). Linking organizational and field-level analyses: The diffusion of corporate environmental practice. Organization \& Environment, 14(2), 133-156.

Huffington Post (2013). First interview since Bangladesh factory collapse, Benetton CEO confirms company's tie to tragedy. Retrieved June 29, 2013, from http://www.huffington post.com/2013/05/08/benetton-bangladesh-factory-colla pse_n_3237991.html.

Huq, F. A., Chowdhury, I. N., \& Klassen, R. D. (2016). Social management capabilities of multinational buying firms and their emerging market suppliers: An exploratory study of the clothing industry. Journal of Operations Management, 46(September 2016), 19-37. https://doi.org/10.1016/j.jom.2016.07.005.

Huq, F. A., Stevenson, M., \& Zorzini, M. (2014). Social sustainability in developing country suppliers: An exploratory study in the ready made garments industry of Bangladesh. International Journal of Operations \& Production Management, 34(5), 610-638.

Hutchins, M. J., \& Sutherland, J. W. (2008). An exploration of measures of social sustainability and their application to supply chain decisions. Journal of Cleaner Production, 16(15), $1688-1698$.

IndustriALL. (2013). Walmart/gap Bangladesh safety plan: Pale imitation of Accord. Retrieved July 22, 2014, from http://www. industriall-union.org/walmart-gap-bangladesh-safety-planpale-imitation-of-accord.

Jacobs, B. W., \& Singhal, V. R. (2017). The effect of the Rana Plaza disaster on shareholder wealth of retailers: Implications for sourcing strategies and supply chain governance. Journal of Operations Management, 49, 52-66.

Jia, F., Zuluaga, L., Bailey, A., \& Rueda, X. (in press). Sustainable supply chain management in developing countries: An analysis of the literature. Journal of Cleaner Production. https://doi. org/10.1016/j.jclepro.2018.03.248.

Jiang, B. (2009). Implementing supplier codes of conduct in global supply chains: Process explanations from theoretic and empirical perspectives. Journal of Business Ethics, 85(1), 77-92. https://doi.org/10.1007/s10551-008-9750-z.

Karjalainen, K., Kemppainen, K., \& van Raaij, E. M. (2008). Noncompliant work behaviour in purchasing: An exploration of reasons behind maverick buying. Journal of Business Ethics, 85(2), 245. https://doi.org/10.1007/s10551-008-9768-2.

Kauppi, K. (2013). Extending the use of institutional theory in operations and supply chain management research: Review and research suggestions. International Journal of Operations \& Production Management, 33(10), 1318-1345. https://doi. org/10.1108/IJOPM-10-2011-0364.

Khanna, T., Palepu, K. G., \& Sinha, J. (2005). Strategies that fit emerging markets. Harvard Business Review, 83(6), 4-19.

Kim, S., Colicchia, C., \& Menachof, D. (2016). Ethical sourcing: An analysis of the literature and implications for future research. Journal of Business Ethics. https://doi.org/10.1007/s1055 1-016-3266-8.

Klassen, R. D., \& Vereecke, A. (2012). Social issues in supply chains: Capabilities link responsibility, risk (opportunity), and performance. International Journal of Production Economics, 140(1), 103-115.

Lee, K.-H., \& Kim, J.-W. (2009). Current status of CSR in the realm of supply management: The case of the Korean electronics industry. Supply Chain Management: An International Journal, 14(2), 138-148. https://doi.org/10.1108/1359854091 0942000 .
Lim, S. J., \& Phillips, J. (2008). Embedding CSR values: The global footwear industry's evolving governance structure. Journal of Business Ethics, 81(1), 143-156.

Lipschutz, R. D. (2004). Sweating it out: NGO campaigns and trade union empowerment. Development in Practice, 14(1/2), 197209. https://doi.org/10.2307/4030125.

Liu, H., Ke, W., Wei, K. K., Gu, J., \& Chen, H. (2010). The role of institutional pressures and organizational culture in the firm's intention to adopt internet-enabled supply chain management systems. Journal of Operations Management, 28(5), 372-384.

Luken, R., \& Stares, R. (2005). Small business responsibility in developing countries: A threat or an opportunity? Business Strategy and the Environment, 14(1), 38-53.

Maignan, I., Hillebrand, B., \& McAlister, D. (2002). Managing socially-responsible buying: How to integrate non-economic criteria into the purchasing process. European Management Journal, 20(6), 641-648.

Maloni, M., \& Benton, W. C. (2000). Power influences in the supply chain. Journal of Business Logistics, 21(1), 49-69.

Mamic, I. (2005). Managing global supply chain: The sports footwear, apparel and retail sectors. Journal of Business Ethics, 59(1), 81-100.

Mani, V., \& Gunasekaran, A. (2018). Four forces of supply chain social sustainability adoption in emerging economies. International Journal of Production Economics, 199, 150-161. https://doi. org/10.1016/j.ijpe.2018.02.015.

Marshall, D., McCarthy, L., Claudy, M., \& McGrath, P. (2016). Piggy in the middle: How direct customer power affects first-tier suppliers' adoption of socially responsible procurement practices and performance. Journal of Business Ethics. https://doi.org/10.1007/ s10551-016-3387-0.

Marshall, D., McCarthy, L., McGrath, P., \& Claudy, M. (2015). Going above and beyond: how sustainability culture and entrepreneurial orientation drive social sustainability supply chain practice adoption. Supply Chain Management: An International Journal, 20(4), 434-454. https://doi.org/10.1108/SCM-08-2014-0267.

McKinsey (2011). Bangladesh ready made garment landscape. Retrieved September 21, 2015, from https://www.mckinsey.com.

Meyer, J. W., \& Rowan, B. (1977). Institutionalized organizations: Formal structure as myth and ceremony. American Journal of Sociology, 83(2), 340-363.

Miles, M., \& Huberman, A. (1994). Qualitative data analysis: An expanded sourcebook. London: Sage.

Miles, M. B., Huberman, A. M., \& Saldaña, J. (2014). Qualitative data analysis: A methods sourcebook. London: Sage.

Montabon, F., Pagell, M., \& Wu, Z. (2016). Making sustainability sustainable. Journal of Supply Chain Management, 52(2), 11-27.

Mueller, M., Dos Santos, V. G., \& Seuring, S. (2009). The contribution of environmental and social standards towards ensuring legitimacy in supply chain governance. Journal of Business Ethics, 89(4), 509-523.

Mundi, L. (2011). A guide to doing business in Bangladesh. Retrieved November 23, 2016, from http://www.lexmundi.com/Document. asp?DocID $=3913$.

New, S. J. (2015). Modern slavery and the supply chain: The limits of corporate social responsibility? Supply Chain Management: An International Journal, 20(6), 697-707. https://doi.org/10.1108/ SCM-06-2015-0201.

New York Times (2012). Documents indicate Walmart blocked safety push in Bangladesh. Retrieved July 25, 2014, from http://www. nytimes.com/2016/12/06/world/asia/3-walmart-suppliersmade-goods-in-bangladeshi-factory-where-112-died-in-fire. $\mathrm{html}$ ?ref=stevengreenhouse\&_r $=1$ \&.

Oliver, C. (1991). Strategic responses to institutional processes. Academy of Management Review, 16(1), 145-179. 
Pagell, M., \& Shevchenko, A. (2014). Why research in sustainable supply chain management should have no future. Journal of Supply Chain Management, 50(1), 44-55.

Pagell, M., \& Wu, Z. (2009). Building a more complete theory of sustainable supply chain management using case studies of 10 exemplars. Journal of Supply Chain Management, 45(2), 37-56. https://doi.org/10.1111/j.1745-493X.2009.03162.x.

Park-Poaps, H., \& Rees, K. (2010). Stakeholder forces of socially responsible supply chain management orientation. Journal of Business Ethics, 92(2), 305-322.

Plambeck, E. L., \& Taylor, T. A. (2015). Supplier evasion of a buyer's audit: Implications for motivating supplier social and environmental responsibility. Manufacturing \& Service Operations Management, 18(2), 184-197.

Pratt, M. G. (2009). For the lack of a boilerplate: Tips on writing up (and reviewing) qualitative research. Academy of Management Journal, 52(5), 856-862. https://doi.org/10.5465/ amj.2009.44632557.

Rogers, K. W., Purdy, L., Safayeni, F., \& Duimering, P. R. (2007). A supplier development program: Rational process or institutional image construction? Journal of Operations Management, 25(2), 556-572. https://doi.org/10.1016/j.jom.2006.05.009.

Saldaña, J. (2013). The coding manual for qualitative researchers. London: Sage.

Sancha, C., Longoni, A., \& Giménez, C. (2015). Sustainable supplier development practices: Drivers and enablers in a global context. Journal of Purchasing and Supply Management, 21(2), 95-102. https://doi.org/10.1016/j.pursup.2014.12.004.

Saunders, M., Lewis, P., \& Thornhill, A. (2009). Research methods for business students. Harlow: Pearson Education.

Scott, W. R. (2008). Approaching adulthood: The maturing of institutional theory. Theory and Society, 37(5), 427-442.

Seuring, S., \& Müller, M. (2008). From a literature review to a conceptual framework for sustainable supply chain management. Journal of Cleaner Production, 16(15), 1699-1710.

Seuring, S. A. (2008). Assessing the rigor of case study research in supply chain management. Supply Chain Management: An International Journal, 13(2), 128-137.

Siggelkow, N. (2007). Persuasion with case studies. The Academy of Management Journal, 50(1), 20-24.

Sine, W. D., \& David, R. J. (2003). Environmental jolts, institutional change, and the creation of entrepreneurial opportunity in the US electric power industry. Research Policy, 32(2), 185-207. https ://doi.org/10.1016/S0048-7333(02)00096-3.

Sroufe, R., Curkovic, S., Montabon, F., \& Melnyk, S. A. (2000). The new product design process and design for environment: "Crossing the chasm". International Journal of Operations \& Production Management, 20(2), 267-291. https://doi.org/10.1108/01443 570010304297

Stake, R. E. (1995). The art of case study research. Thousand Oaks, CA: Sage Publications.

Tencati, A., Quaglia, V., \& Russo, A. (2008). Unintended consequences of CSR: protectionism and collateral damage in global supply chains: The case of Vietnam. Corporate Governance, 8(4), 518531. https://doi.org/10.1108/14720700810899248.

Thornton, P., Ocasio, W., \& Lounsbury, M. (2012). The institutional logics perspective: A new approach to culture, structure, and process. Oxford: Oxford University Press.

Thornton, P. H., Jones, C., \& Kury, K. (2005). Institutional logics and institutional change in organizations: Transformation in accounting, architecture, and publishing. In C. Jones \& P. H. Thornton (Eds.), Transformation in cultural industries. Research in the sociology of organizations. (Vol. 23, pp. 125-170). Bingley: Emerald Group Publishing Limited.
Thornton, P. H., \& Ocasio, W. (1999). Institutional logics and the historical contingency of power in organizations: Executive succession in the higher education publishing industry, 1958-1990. American Journal of Sociology, 105(3), 801-843. https://doi. org/10.1086/210361.

Time (2013). Wake of Rana Plaza tragedy, Bangladesh garment-factory inspections floundering. Retrieved October 3, 2013, from http:// world.time.com/2013/09/12/in-wake-of-rana-plaza-tragedybangladesh-garment-factory-inspections-floundering/.

Touboulic, A., \& Walker, H. (2015). Theories in sustainable supply chain management: A structured literature review. International Journal of Physical Distribution \& Logistics Management, 45(1/2), 16-42. https://doi.org/10.1108/IJPDLM-05-2013-0106.

Transparency International (2016). CPI 2016: Bangladesh slightly improves scores and ranking. Retrieved March 16, 2018, from https://www.ti-bangladesh.org/beta3/index.php/en/media-relea se/5151-cpi-2016-bangladesh-slightly-improves-scores-andranking.

Tsoi, J. (2010). Stakeholders' perceptions and future scenarios to improve corporate social responsibility in Hong Kong and Mainland China. Journal of Business Ethics, 91(3), 391-404. https:// doi.org/10.1007/s10551-009-0091-3.

UK Trade \& Investment (2015). Exporting to Bangladesh. Retrieved November 23, 2016, from https://www.gov.uk/government/publi cations/exporting-to-bangladesh/doing-business-in-bangladesh -bangladesh-trade-and-export-guide.

Vachon, S., \& Klassen, R. D. (2008). Environmental management and manufacturing performance: The role of collaboration in the supply chain. International Journal of Production Economics, 111(2), 299-315.

van Teijlingen, E., \& Hundley, V. (2001). The importance of pilot studies. Retrieved October 27, 2012, from http://www.soc.surrey.ac. uk/sru/SRU35.html.

Voss, C., Tsikriktsis, N., \& Frohlich, M. (2002). Case research in operations management. International Journal of Operations \& Production Management, 22(2), 195-219.

Walker, H., Di Sisto, L., \& McBain, D. (2008). Drivers and barriers to environmental supply chain management practices: Lessons from the public and private sectors. Journal of Purchasing and Supply Management, 14(1), 69-85. https://doi.org/10.1016/j. pursup.2008.01.007.

Walker, H., \& Jones, N. (2012). Sustainable supply chain management across the UK private sector. Supply Chain Management: An International Journal, 17(1), 15-28.

Wilhelm, M. M., Blome, C., Bhakoo, V., \& Paulraj, A. (2016). Sustainability in multi-tier supply chains: Understanding the double agency role of the first-tier supplier. Journal of Operations Management, 41, 42-60. https://doi.org/10.1016/j.jom.2015.11.001.

Woods, M., Macklin, R., \& Lewis, G. K. (2016). Researcher reflexivity: Exploring the impacts of CAQDAS use. International Journal of Social Research Methodology, 19(4), 385-403. https://doi. org/10.1080/13645579.2015.1023964.

Wu, Z., \& Pagell, M. (2011). Balancing priorities: Decision-making in sustainable supply chain management. Journal of Operations Management, 29(6), 577-590. https://doi.org/10.1016/j. jom.2010.10.001.

Wu, Z., Choi, T. Y., \& Rungtusanatham, M. J. (2010). Supplier-supplier relationships in buyer-supplier-supplier triads: Implications for supplier performance. Journal of Operations Management, 28(2), 115-123. https://doi.org/10.1016/j.jom.2009.09.002.

Wu, Z., \& Pullman, M. E. (2015). Cultural embeddedness in supply networks. Journal of Operations Management, 37, 45-58.

Yawar, S. A., \& Seuring, S. (2015). Management of social issues in supply chains: A literature review exploring social issues, actions and performance outcomes. Journal of Business Ethics, 1-23. 
Yin, R. (2009). Case study research: Design and methods (4th edn.). Thousand Oaks: Sage.

Yu, X. (2008). Impacts of corporate code of conduct on labor standards: A case study of Reebok's athletic footwear supplier factory in China. Journal of Business Ethics, 81(3), 513-529. https://doi. org/10.1007/s10551-007-9521-2.

Zhao, X., Huo, B., Flynn, B. B., \& Yeung, J. H. Y. (2008). The impact of power and relationship commitment on the integration between manufacturers and customers in a supply chain. Journal of Operations Management, 26(3), 368-388. https://doi. org/10.1016/j.jom.2007.08.002.

Zhou, K. Z., Su, C., Yeung, A., \& Viswanathan, S. (2016). Supply chain management in emerging markets. Journal of Operations Management, 46, 1-4. https://doi.org/10.1016/j.jom.2016.07.007.

Zhou, K. Z., Zhang, Q., Sheng, S., Xie, E., \& Bao, Y. (2014). Are relational ties always good for knowledge acquisition? Buyer-supplier exchanges in China. Journal of Operations Management, 32(3), 88-98. https://doi.org/10.1016/j.jom.2014.01.001.
Zhu, Q., \& Sarkis, J. (2007). The moderating effects of institutional pressures on emergent green supply chain practices and performance. International Journal of Production Research, 45(18/19), 4333-4355. https://doi.org/10.1080/00207540701440345.

Zorzini, M., Hendry, L. C., Huq, F. A., \& Stevenson, M. (2015). Socially responsible sourcing: Reviewing the literature and its use of theory. International Journal of Operations \& Production Management, 35(1), 60-109. https://doi.org/10.1108/IJOPM -07-2013-0355.

Zsidisin, G. A., Melnyk, S. A., \& Ragatz, G. L. (2005). An institutional theory perspective of business continuity planning for purchasing and supply management. International Journal of Production Research, 43(16), 3401-3420. https://doi.org/10.1080/00207 540500095613.

Zucker, L. G. (1987). Institutional theories of organization. Annual Review of Sociology, 1987(13), 443-464. 